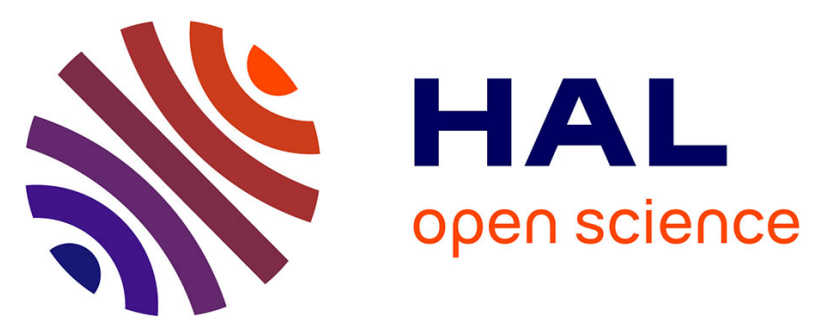

\title{
Jurassic-Early Cenozoic Tectonic Inversion in the Qilian Shan and Qaidam Basin, North Tibet: New Insight From Seismic Reflection, Isopach Mapping, and Drill Core Data
}

Feng Cheng, Marc Jolivet, Zhaojie Guo, Huayu Lu, Bo Zhang, Xiangzhong Li, Daowei Zhang, Changhao Zhang, Hanzhi Zhang, Lin Wang, et al.

\section{To cite this version:}

Feng Cheng, Marc Jolivet, Zhaojie Guo, Huayu Lu, Bo Zhang, et al.. Jurassic-Early Cenozoic Tectonic Inversion in the Qilian Shan and Qaidam Basin, North Tibet: New Insight From Seismic Reflection, Isopach Mapping, and Drill Core Data. Journal of Geophysical Research : Solid Earth, 2019, 124 (11), pp.12077-12098. 10.1029/2019JB018086 . insu-02371780

\section{HAL Id: insu-02371780 \\ https://hal-insu.archives-ouvertes.fr/insu-02371780}

Submitted on 20 Nov 2019

HAL is a multi-disciplinary open access archive for the deposit and dissemination of scientific research documents, whether they are published or not. The documents may come from teaching and research institutions in France or abroad, or from public or private research centers.
L'archive ouverte pluridisciplinaire HAL, est destinée au dépôt et à la diffusion de documents scientifiques de niveau recherche, publiés ou non, émanant des établissements d'enseignement et de recherche français ou étrangers, des laboratoires publics ou privés. 


\section{RESEARCH ARTICLE 10.1029/2019JB018086 \\ Key Points: \\ - Mesozoic strike-slip motion along the Altyn Tagh Fault (ATF) shearing zone controlled the formation of transtensional basins \\ - Change in the direction of regional stress field occurred during the Late Jurassic-Early Cretaceous \\ - The Qilian Shan and the Qaidam Basin were completely inverted under a N-S or NE-SW oriented compression during the Early Cenozoic}

Supporting Information:

- Supporting Information S1

- Table S1

Correspondence to:

F. Cheng and L. Wang,

cfcf.chengfeng@gmail.com;

linzi@pku.edu.cn

Citation:

Cheng, F., Jolivet, M., Guo, Z., Lu, H., Zhang, B., Li, X., et al. (2019).

Jurassic-Early Cenozoic tectonic inversion in the Qilian Shan and Qaidam Basin, North Tibet: New insight from seismic reflection, isopach mapping, and drill core data. Journal of Geophysical Research: Solid Earth, 124. https://doi.org/10.1029/ 2019JB018086

Received 23 MAY 2019 Accepted 8 OCT 2019

Accepted article online 10 NOV 2019

\section{Jurassic-Early Cenozoic Tectonic Inversion in the Qilian Shan and Qaidam Basin, North Tibet: New Insight From Seismic Reflection, Isopach Mapping, and Drill Core Data}

\author{
Feng Cheng ${ }^{1,2,3}$ iD, Marc Jolivet ${ }^{4}$, Zhaojie Guo ${ }^{3}$ iD, Huayu Lu $^{5}$ (D), Bo Zhang ${ }^{3}$ iD, \\ Xiangzhong Lid ${ }^{2,6,7}$ (D), Daowei Zhang ${ }^{8}$, Changhao Zhang ${ }^{8}$, Hanzhi Zhang ${ }^{5}$ (D), Lin Wang', \\ Zhenqiang Wang $^{8}$, and Qiquan Zhang ${ }^{8}$ \\ ${ }^{1}$ Department of Earth and Environmental Sciences, University of Rochester, Rochester, NY, USA, ${ }^{2}$ State Key Laboratory \\ of Loess and Quaternary Geology, Institute of Earth Environment, Chinese Academy of Sciences, Xi'an, China, ${ }^{3}$ Key \\ Laboratory of Orogenic Belts and Crustal Evolution, Ministry of Education, School of Earth and Space Sciences, Peking \\ University, Beijing, China, ${ }^{4}$ Université de Rennes - CNRS-UMR6118, Laboratoire Géosciences Rennes, Observatoire des \\ Sciences de l'Univers, Rennes, France, ${ }^{5}$ School of Geography and Ocean Science, Nanjing University, Nanjing, China, \\ ${ }^{6}$ Research Center for Earth System Science, Yunnan University, Kunming, China, ${ }^{7}$ Yunnan Key Laboratory of Earth \\ System Science, Yunnan University, Kunming, China, ${ }^{8}$ Qinghai Oilfield Company, PetroChina, Dunhuang, China \\ ${ }^{9}$ College of Engineering, Peking University, Beijing, China
}

(c)2019. American Geophysical Union. All Rights Reserved.

\begin{abstract}
The pre-Cenozoic structural pattern of Asia has had a strong impact on the localization and propagation of the Cenozoic deformation that gave birth to the Tibetan Plateau. Northern Tibet represents a key area to decipher the structural and kinematic links between the Mesozoic and Cenozoic evolution of Tibet. Nonetheless, the Mesozoic tectonic setting of the North Tibet and the role that the Paleozoic inherited Altyn Tagh Fault (ATF) shearing zone played in controlling the regional tectonic pattern during the deposition of the Mesozoic strata remain controversial. This study is based on seismic reflections, isopach maps of the Mesozoic strata in the Qaidam Basin, and provenance analysis using detrital zircon geochronological and heavy mineral contents. Seismic reflections and isopach maps demonstrate that sustained strike-slip motion along the ATF during the Early to Late Jurassic induced transtensional basin formation. Further away from the main ATF (eastern parts of the Qilian Shan and the northern Qaidam Basin), transtension also occurred along major faults, although local transpression developed in relay zones. Rotation in the regional stress field induced compression and basin inversion during the Late Jurassic to Early Cretaceous. The Cenozoic sedimentary rocks in these regions display widespread growth strata and angular unconformities characteristic of compression. This is consistent with topographic changes marked by sediment source variation evidenced by detrital zircon geochronology and heavy mineral analysis. We propose that the mechanism driving the Jurassic extension/transtension in North Tibet could be related to far-field effects of subduction processes along the southern margins of the continent.
\end{abstract}

\section{Introduction}

Defining the northeastern boundary of the modern Tibetan Plateau, the Qilian Shan mountain belt (at >4,000 $\mathrm{m}$ high on average) and the Qaidam Basin (the largest topographic depression in the plateau) occupy a transition zone between the high-elevation plateau and the adjacent low-elevation Tarim and Ordos cratons to the north/northeast (Figure 1). It is acknowledged that the Cenozoic growth of the Qilian Shan and the contemporaneous development of the Qaidam Basin were related to indentation of India into Asia since approximately 65-50 Ma (Bovet et al., 2009; Hu et al., 2016; M. Jolivet et al., 2001; Meyer et al., 1998; Tapponnier et al., 2001; Yin \& Harrison, 2000; Yin et al., 2002; Zhuang et al., 2011; Zuza et al., 2017). However, crustal and lithospheric structures active during pre-Himalayan orogenesis also played a significant role in the topographic and tectonic evolution of the modern Tibetan Plateau (Cheng et al., 2016; Cheng, Garzione, Jolivet, Guo, et al., 2019; Cheng, Garzione, Jolivet, Wang, et al., 2019; Ding et al., 2014; Marc Jolivet et al., 2018; Tian et al., 2016). In that respect, a better understanding of the Mesozoic structural pattern and associated kinematics in the Qilian Shan and Qaidam Basin can provide 

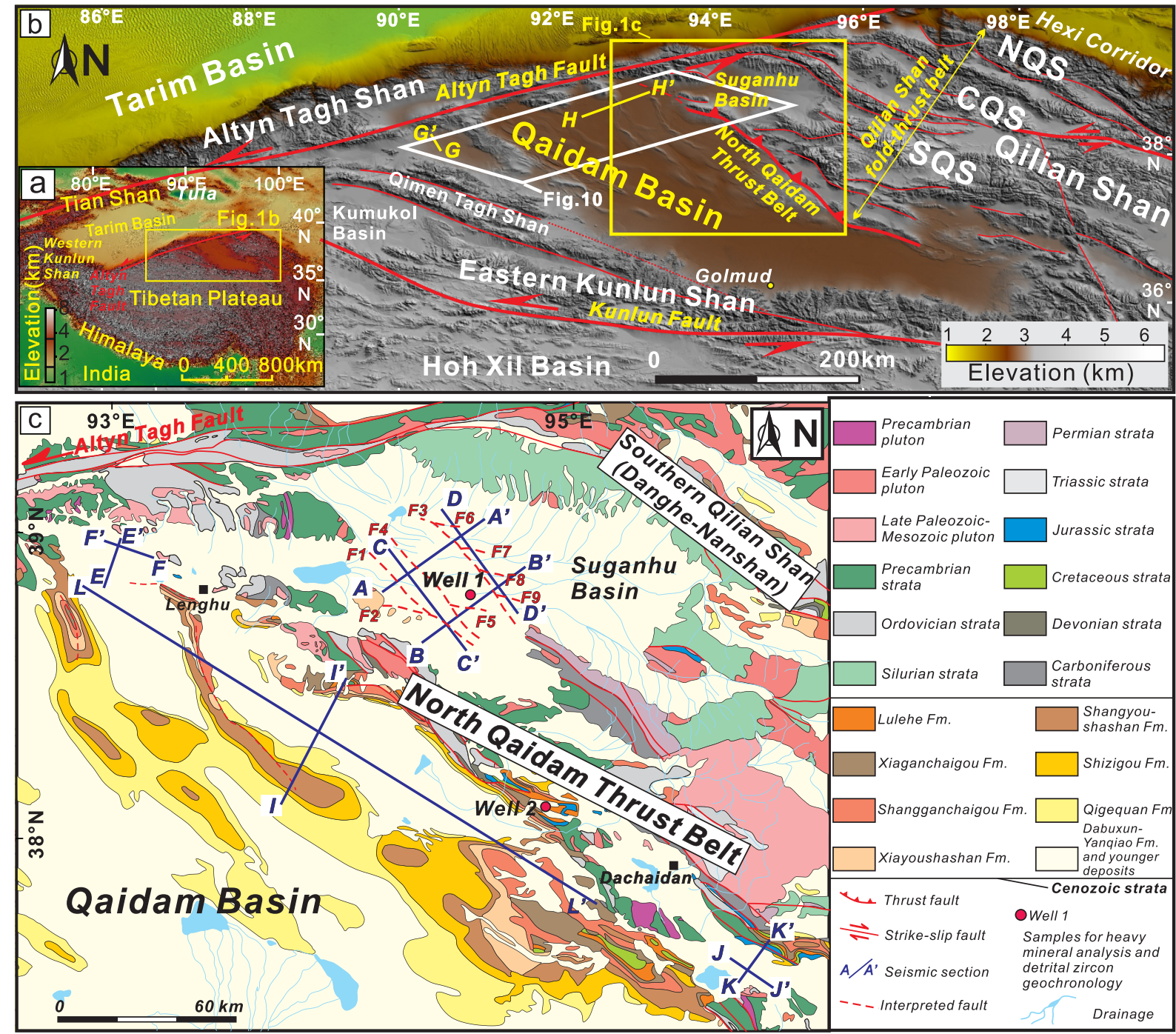

Figure 1. Topographic map of the (a) Tibetan plateau and the (b) North Tibet. NQS, CQS, and SQS refer to northern Qilian Shan, central Qilian Shan, and southern Qilian Shan, respectively. (c) Geological map of the NE Qaidam Basin, Suganhu Basin, and southern Qilian Shan.

significant insights into the growth mechanism of the northern region of the Tibetan Plateau during the Cenozoic. In particular, two critical questions must be addressed: (1) what was the geodynamic setting of the Qilian Shan-Qaidam region during the Mesozoic? (2) Did the Paleozoic inherited Altyn Tagh Fault (ATF) shearing zone play a role in the regional tectonic evolution of the Qilian Shan-Qaidam system during the Mesozoic?

Whereas it is commonly accepted that the northern margin of Tibet underwent compressional deformation during the Cretaceous (Ritts \& Biffi, 2001; L. Wu et al., 2011; Yin, Dang, Wang, et al., 2008; Yu et al., 2017), the Jurassic tectonic setting of the Qilian Shan and Qaidam Basin has been debated for many years. Based on sedimentary and stratigraphic information obtained from Jurassic strata exposed along the southern flank of the Qilian Shan, Ritts and Biffi (2001) argued for a contractional regime under which the northern Qaidam Basin behaved as a foreland basin related to southward thrusting of the Qilian Shan. In contrast, based on interpretation of regional seismic profiles across the northern Qaidam Basin and on provenance analysis of Jurassic clastic series deposited in the northern Qaidam Basin and Qilian Shan region, some recent studies suggested that the Jurassic sedimentation and structural pattern in the northern Qaidam Basin resulted from regional extension or transtension (Lou et al., 2009; L. Wu et al., 2011; Yin, Dang, Wang, et al., 2008; Yu et al., 2017; Zuza et al., 2017). Nonetheless, the Jurassic tectonic setting of the Qaidam basin as well as the relation between the range and the basin remains controversial as few direct evidence of normal faulting along the 
basin margin has been reported (L. Wu et al., 2011; Yin, Dang, Wang, et al., 2008; Yin, Dang, Zhang, et al., 2008).

Apatite and zircon fission track analysis on basement rocks and ${ }^{40} \mathrm{Ar} /{ }^{39} \mathrm{Ar}$ analyses of syntectonic sediments along the ATF have revealed a cooling event during the Jurassic, interpreted as reactivation (shearing) of the ATF (Delville et al., 2001; M. Jolivet et al., 2001; H. Li et al., 2006; Liu et al., 2007; Sobel et al., 2001; Y. Wang et al., 2005). The potential role of the reactivation of the ATF system on the Jurassic tectonic and topographic evolution of the Qilian Shan and the Qaidam Basin is still not understood. To a wider scale, the mechanism that controlled the Jurassic tectonics in North Tibet remains to be described (Ritts \& Biffi, 2001; Sobel et al., 2001; Vincent \& Allen, 1999; Y. Wang et al., 2005; Yin \& Harrison, 2000; Yu et al., 2017). For instance, if shearing along the ATF led to a regional crustal extension in the Qilian Shan - Qaidam region, one would expect to see a series of Jurassic extensional features adjacent to the fault zone gradually disappearing away from the main shear zone.

The difficulty in determining the Jurassic tectonic pattern of the Qilian Shan and Qaidam Basin is largely related to the lack of geological information within the remote Qilian Shan. Furthermore, the limited outcrops of Jurassic deposits available in this region are strongly overprinted by the Cretaceous and Cenozoic deformation events (Bovet et al., 2009; Cheng et al., 2015; Cheng et al., 2016; Jolivet et al., 2001; Meng et al., 2001; Ritts \& Biffi, 2001; Ritts et al., 1999; Sobel et al., 2001; C, Wu et al., 2016; Wu et al., 2011; Yin, Dang, Wang, et al., 2008; Yin, Dang, Zhang, et al., 2008; Yu et al., 2017; Zuza et al., 2017). Additionally, most of the Jurassic strata are deeply buried (as deep as $>10 \mathrm{~km}$ ) beneath the surface of the Qaidam Basin (Meng et al., 2001; Yin, Dang, Zhang, et al., 2008), with only a few residual Jurassic strata sporadically exposed along the ATF and within a few thrusts systems in the Qilian Shan (Figure 1).

This study relies on 12 seismic profiles across the southern Qilian Shan and northern Qaidam Basin to describe the Jurassic tectonic pattern along the ATF zone, the southern Qilian Shan, and along the northern Qaidam Basin. These seismic data are complemented by two isopach maps of the Qaidam Basin that correspond to the Early to Middle Jurassic and Late Jurassic to Cretaceous time intervals. In addition, provenance analysis (detrital zircon U-Pb geochronology and heavy minerals analysis) on drill core samples from the southern Qilian Shan are used to decipher the source to sink relation between the Qilian Shan and the Qaidam Basin during the Jurassic. Our work provides direct evidence for Early to Middle Jurassic crustal extension in the western part of the Qilian Shan. During this period, strike-slip movement along faults in the ATF shearing zone was gradually accommodated by the transpressional or transtensional tectonics eastward in the northern Qaidam Basin, allowing for eastward crustal extrusion. Although this remains to be documented in much more details, we discuss the potential mechanism that drove extensional tectonics in central Asia during the Early to Middle Jurassic. Finally, the northern Qaidam Basin was inverted by the Late Jurassic to Early Cenozoic compression that also affected the Qilian Shan.

\section{Regional Geology}

\subsection{Qilian Shan and Northern Qaidam Basin Along the Altyn Tagh Fault}

Separating the Tibetan Plateau from the Tarim craton, the lithospheric strike-slip ATF extends for over 1,600 $\mathrm{km}$ from the Western Kunlun Shan, crossing the Altyn Tagh Shan, to the northwestern end of the Qilian Shan (Burchfiel et al., 1989; Yin \& Harrison, 2000; Figure 1). Some studies argue that the ATF could be linked eastward with NE-SW striking structures extending toward Mongolia (Darby et al., 2005; Y Yue \& Liou, 1999; Yue et al., 2001). The estimates of the cumulative sinistral displacement on the fault vary between approximately 300 and approximately $500 \mathrm{~km}$ in general (Cheng et al., 2015; Cheng, Guo, et al., 2015; Cheng, Jolivet, et al., 2016; Cowgill et al., 2003; Ritts \& Biffi, 2000; Yin et al., 2002; Yin \& Harrison, 2000).

The Qilian Shan is bordered by the Qaidam Basin to the south, the Hexi Corridor to the northeast, and truncated by the left-lateral strike-slip ATF to the west (Figure 1). The belt consists of several subparallel NW-SE to NWW-SEE trending ranges that develop on folds, thrusts, and/or strike-slip faults accommodating the northward motion of the Tibetan Plateau (Allen et al., 2017; Meyer et al., 1998; Yin et al., 2002; Figure 1). Based on their lithological composition, the Qilian Shan has been divided into four terranes, namely, the northern Qilian Shan (NQS), the central Qilian Shan (CQS), the southern Qilian Shan (SQS), and the 
Table 1

Mesozoic and Cenozoic Stratigraphy in the Qilian Shan and Qaidam Basin

\begin{tabular}{|c|c|c|c|}
\hline Formation & Symbol & Age (Ma) with their source & \\
\hline $\begin{array}{l}\text { Including Dabuyun-Yanqiao } \\
\text { formation and younger deposits }\end{array}$ & $\mathrm{Q}_{2-4}$ & 0.01 to present (Yin et al., 2007) & \\
\hline Qigequan & $\mathrm{Q}_{1}$ & 2.5-0.01 (Fang et al., 2007; Yin et al., 2007) & \\
\hline Shizigou & $\mathrm{N}_{2}{ }^{3}$ & $8.1-2.5$ (Fang et al., 2007) & 6.3-2.5 (W. Wang et al., 2017) \\
\hline Shangyoushashan & $\mathrm{N}_{2}^{2}\left(\right.$ or $\left.\mathrm{N}_{1}^{3 \mathrm{a}}\right)$ & 15.3-8.1 (Fang et al., 2007; Ji et al., 2017) & 9.0-6.3 (W. Wang et al., 2017) \\
\hline Xiayoushashan & $\mathrm{N}_{2}{ }^{1}\left(\right.$ or $\left.\mathrm{N}_{1}{ }^{2 a}\right)$ & 22.0-15.3 (Fang et al., 2007; Lu \& Xiong, 2009) & 11.1-9.0 W.Wang et al., 2017) \\
\hline Shangganchaigou & $\mathrm{N}_{1}\left(\right.$ or $\left.\mathrm{N}_{1}^{1 \mathrm{a}^{\prime}}\right)$ & 35.5-22.0 (Lu \& Xiong, 2009; Sun et al., 2005) & 16.5-11.1 (W. Wang et al., 2017) \\
\hline Upper Xiaganchaigou & $\mathrm{E}_{3}{ }^{2}$ & 37.8-35.5 (Pei et al., 2009; Sun et al., 2005) & 23.5-16.5 (W. Wang et al., 2017) \\
\hline Lower Xiaganchaigou & $\mathrm{E}_{3}^{1}$ & 43.8-37.8 (Pei et al., 2009; W. Zhang, 2006) & \\
\hline Lulehe & $\mathrm{E}_{1}+2$ & >53.5-43.8 (Ke et al., 2013; Yang et al., 1992; W. Zhang, 2006) & $>29.5-23.5$ (W. Wang et al., 2017) \\
\hline Quanyagou & $\mathrm{K}_{1}$ & Early Cretaceous (ECS, 2009) & \\
\hline Hongshuigou and Caishiling & $\mathrm{J}_{3}$ & Late Jurassic (QBGMR, 1991) & \\
\hline Dameigou and Xiaomeigou & $\mathrm{J}_{1 \_2}$ & Early to Middle Jurassic (Ritts et al., 1999; Ritts \& Biffi, 2001) & \\
\hline
\end{tabular}

${ }^{a}$ Note that symbol N1 usually represents Miocene time while N2 represents Pliocene time. Given that the symbols $\mathrm{N}_{2}{ }^{2}, \mathrm{~N}_{2}{ }^{1}$, and $\mathrm{N}_{1}$ for Shangyoushashan formation, Xiayoushashan formation, and Shangganchaigou formation, respectively, have been widely used in petroleum exploration and geological survey (L. Wu et al., 2014; Yin et al., 2007), we thus follow the traditional division in this study.

North Qaidam Thrust Belt (NQTB; Bovet et al., 2009; Gehrels et al., 2003; Ritts et al., 2004). Within this region, the intermontane Suganhu Basin is bordered by the NQTB to the south, the SQS to the north, and truncated by the ATF to the west (Figure 1).

The Qaidam Basin is surrounded by the Eastern Kunlun Shan to the south, the Altyn Tagh Shan to the northwest, and the Qilian Shan to the northeast (Figure 1). Both the Qaidam Basin and the Qilian Shan underwent multiple phases of deformation since the Mesozoic and accommodated considerable crustal thickening during the Cenozoic in response to the India-Asia collision and postcollisional convergence (S. Fu et al., 2015; Meng \& Fang, 2008; Meyer et al., 1998; Ritts \& Biffi, 2001; Sobel et al., 2001; E. Wang et al., 2006; L. Wu et al., 2011; Xia et al., 2001; Yin, Dang, Wang, et al., 2008; Yin, Dang, Zhang, et al., 2008; Yin et al., 2002; Zhuang et al., 2011). Based on apatite and zircon fission track analysis and ${ }^{40} \mathrm{Ar} /$

${ }^{39} \mathrm{Ar}$ thermochronology, previous studies have revealed a series of Jurassic and Cretaceous cooling events in the Qilian Shan and along the margins of the Qaidam Basin, interpreted as tectonic deformation phases (Arnaud et al., 2003; Delville et al., 2001; Jolivet et al., 2001; Liu et al., 2007; Pan et al., 2013; Qi et al., 2016; Sobel et al., 2001; Wang et al., 2005). However, whether these Mesozoic tectonic events corresponded to extensional or contractional deformation is still debated (Ritts \& Biffi, 2001; Sobel et al., 2001; Yin, Dang, Wang, et al., 2008; Yu et al., 2017).

\subsection{Mesozoic to Cenozoic Stratigraphy in the Studied Area}

Despite the fact that geological mapping suggests a lack of Mesozoic and Cenozoic outcrops in the Qilian Shan and Qaidam Basin, geophysical surveys for petroleum exploration have revealed several interrange depressions in the Qilian Shan and the Qaidam Basin that contain thick Mesozoic to Cenozoic nonmarine deposits unconformably overlying Precambrian to Triassic basement and sedimentary rocks (Cheng et al., 2017; Meng \& Fang, 2008; Xia et al., 2001; Yin, Dang, Zhang, et al., 2008). The ages of the Jurassic and Cretaceous strata have been determined based on paleontological analysis of outcrop and drill core samples (QBGMR, 1991; Ritts \& Biffi, 2000; Ritts et al., 1999; Wu et al., 2011; Table 1). The Early to Middle Jurassic $\left(\mathrm{J}_{1 \_2}\right)$ strata consists mainly of greyish to greenish conglomerate and greyish sandstone intercalated with dark shale and coal, corresponding to fluvial to lacustrine facies (Cheng, Guo, et al., 2015; Ritts et al., 1999; Ritts \& Biffi, 2000, 2001; Wu et al., 2011; Yu et al., 2017). The Late Jurassic deposits $\left(\mathrm{J}_{3}\right)$ are dominated by brownish sandstone intercalated with brownish siltstone and greyish conglomerate, generally associated to fluvial depositional environment (Cheng, Guo, et al., 2015; Ritts \& Biffi, 2000, 2001; Ritts et al., 1999; Wu et al., 2011; Yu et al., 2017; Figures 2 and 3). The few preserved Early Cretaceous strata mainly consist of variegated conglomerate and reddish pebbly sandstone intercalated with reddish siltstone and claystone, corresponding to alluvial to fluvial lithofacies (. The Middle and Late Cretaceous strata are missing. 


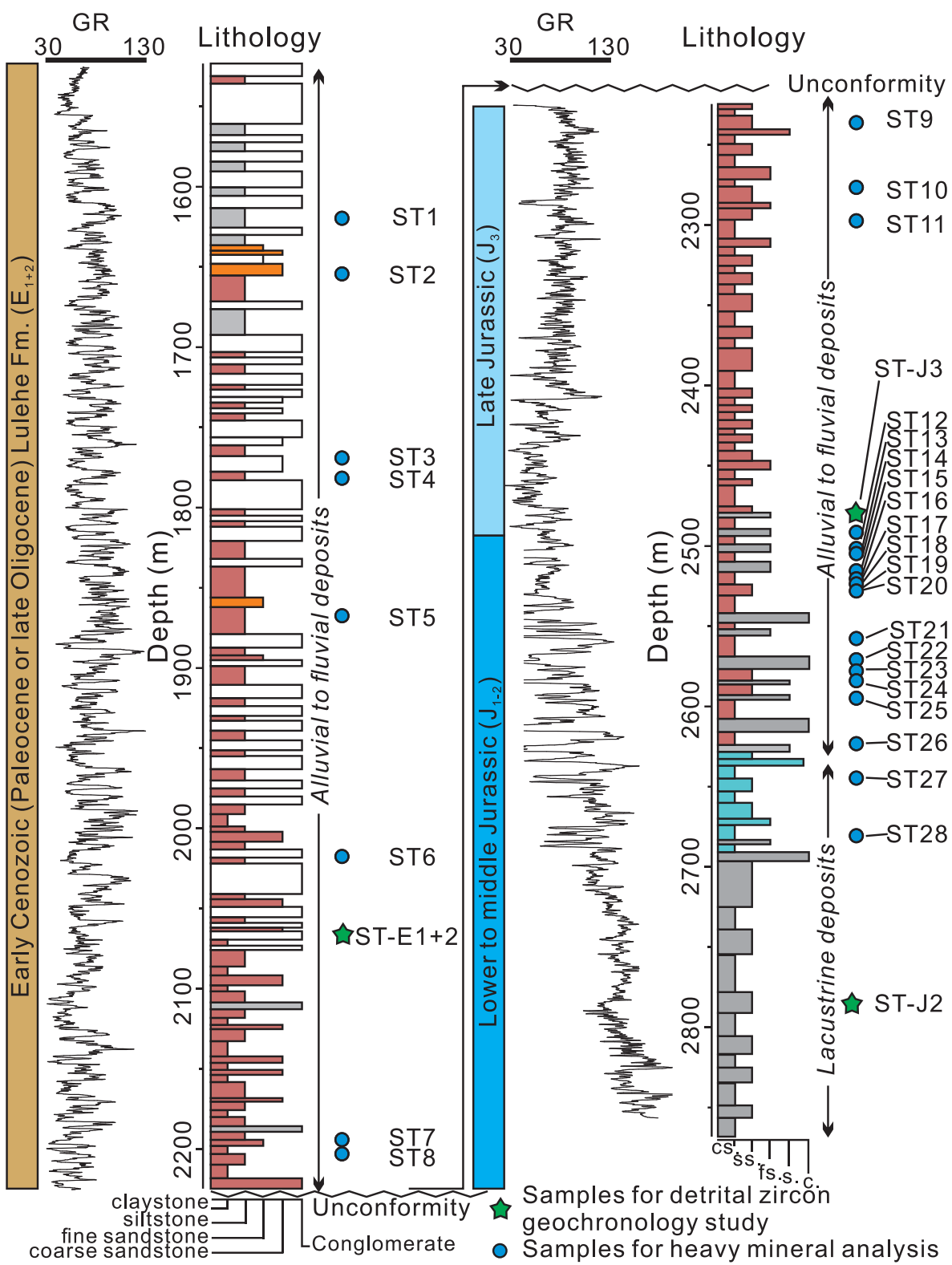

Figure 2. Lithology column of the Jurassic to Early Cenozoic strata in the drilling well in Suganbu Basin, western part of the Qilian Shan. The location of the strata is shown in Figure 1c. Gamma Ray (GR) is provided by the Qinghai Oilfield Company, PetroChina.

Field investigation and drill core observation suggest that the Cenozoic strata are predominately composed of alluvial, fluvial, and lacustrine deposits (Cheng et al., 2018; Meng \& Fang, 2008; Xia et al., 2001). The Cenozoic series within the basin is subdivided into eight lithostratigraphic units, from the oldest to the youngest (followed by symbol for each unit): (1) the Lulehe formation, $E_{1+2} l$; (2) the lower Xiaganchaigou formation, $\mathrm{E}_{3}{ }^{1} \mathrm{xg}$; (3) the upper Xiaganchaigou formation, $\mathrm{E}_{3}{ }^{2} \mathrm{xg}$; (4) the Shangganchaigou formation, $\mathrm{N}_{1} \mathrm{sg}$; (5) the Xiayoushashan formation, $\mathrm{N}_{2}{ }^{1} \mathrm{xy}$; (6) the Shangyoushashan formation, $\mathrm{N}_{2}{ }^{2} \mathrm{sy}$; (7) the Shizigou formation, $\mathrm{N}_{2}{ }^{3} \mathrm{~s}$; and (8) the Qigequan formation ( $\mathrm{Q}_{1} \mathrm{q}$; Table 1 and Figure 2). The Lulehe formation is generally considered to be Paleocene to Early Eocene in age based on magnetostratigraphy, spore, and pollen assemblages (Cheng et al., 2018; Ji et al., 2017; Ke et al., 2013; Rieser et al., 2006a; Rieser et al., 2006b; X Wang et al., 2007; Xia et al., 2001; Yang et al., 1992; Yin, Dang, Zhang, et al., 2008; Yin et al., 2002; W Zhang, 2006; Zhuang et al., 2011). However, a recent magnetostratigraphy and detrital geochronology study of the Lulehe formation near the type locality in the northern Qaidam Basin suggests an 30-25-Ma depositional 

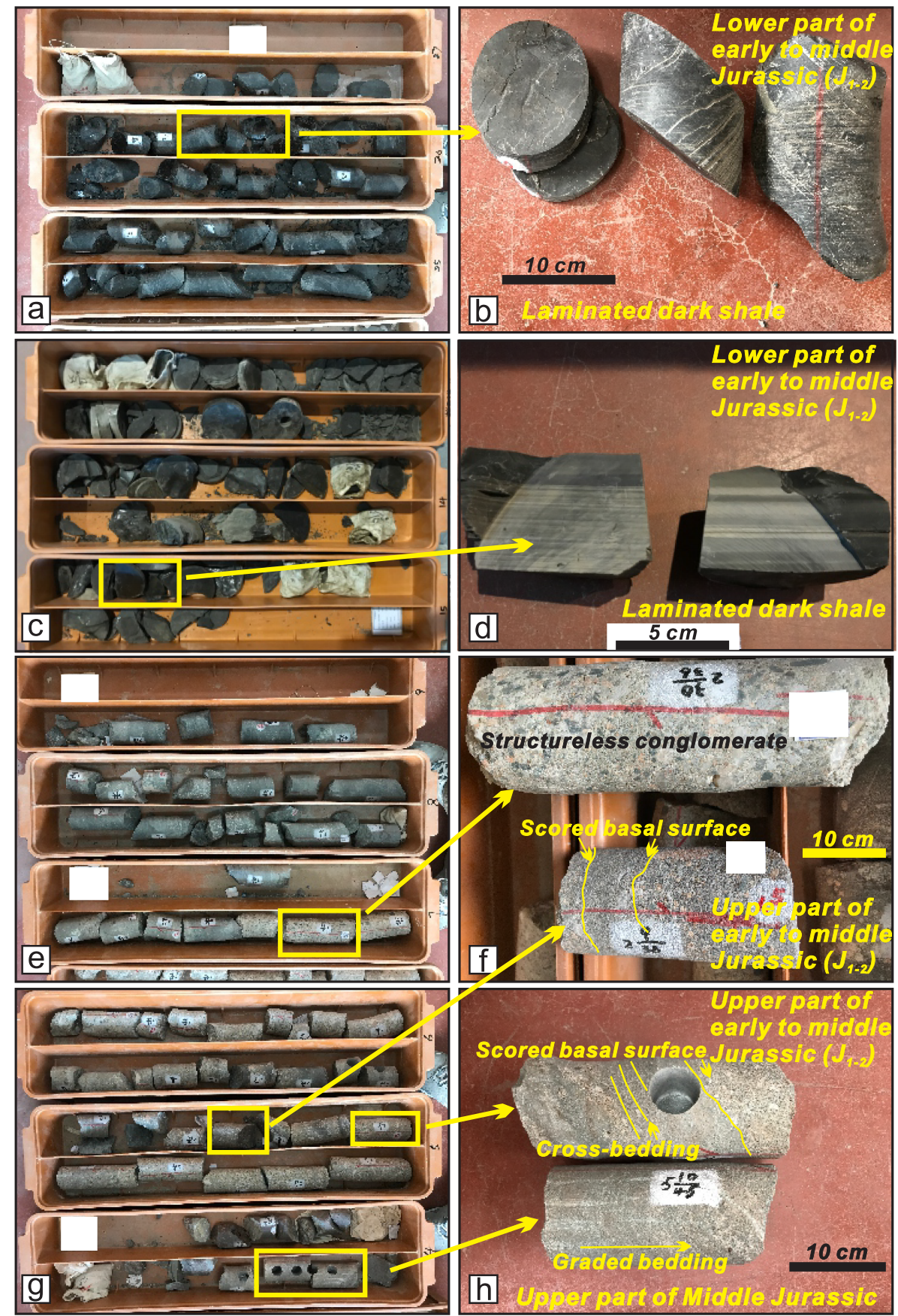

Figure 3. Images of typical sedimentary structures represented in drill core samples.

age (W Wang et al., 2017), underscoring the need for further work to determine the depositional age of the Cenozoic strata in this region (Cheng et al., 2018; Cheng, Garzione, Jolivet, Wang, et al., 2019).

\section{Sampling and Analytical Methods}

\subsection{Isopach Maps of the Mesozoic Strata and Detailed Seismic Profile Interpretation}

To assess the depositional pattern, temporal-spatial thickness distribution, and migration of the major depocenters in the Qaidam Basin during the Mesozoic, two isopach maps (corresponding to the Early to Middle Jurassic and Late Jurassic to Early Cretaceous time intervals, respectively) were obtained from the Qinghai Oilfield Company, PetroChina (Figure 4). These maps represent a compilation of surface and subsurface 


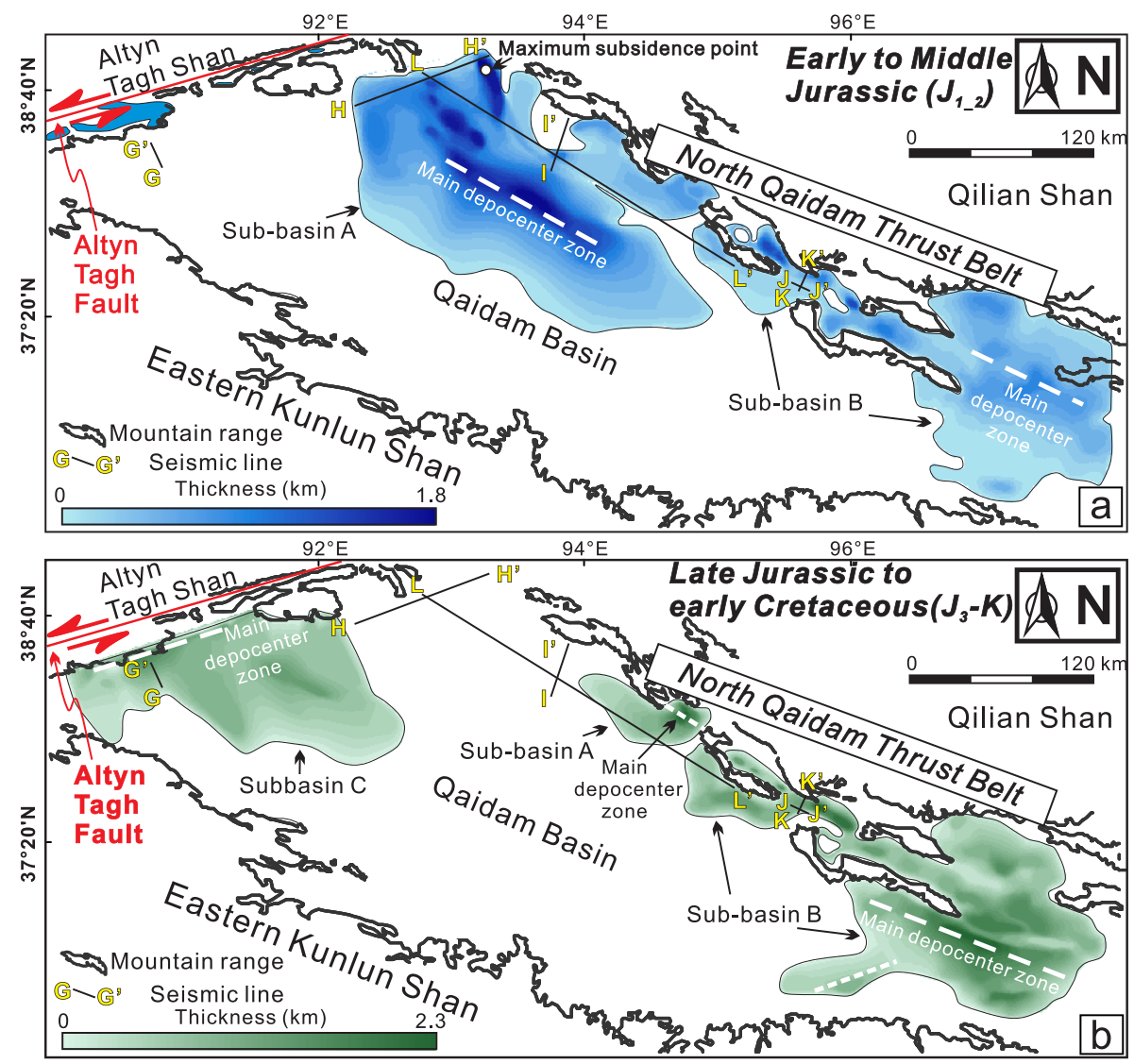

Figure 4. Isopach maps of the Early to Middle Jurassic strata $\left(\mathrm{J}_{1-2}\right)$ and Late Jurassic to Early Cretaceous strata $\left(\mathrm{J}_{3}-\mathrm{K}\right)$ in the Qaidam Basin.

data collected from decades of drilling and a dense network of seismic lines. Although numerous wells have penetrated the basin margins, only a few wells reached the Mesozoic series close to the center of the basin due to the large thickness of the Cenozoic cover. Therefore, the estimate of Mesozoic strata thickness in the center of the basin mainly depends on the regional seismic profile interpretation. Despite lack of ties between seismic reflection data and wells, this is the best data set available so far.

In order to describe the structural pattern in the Qilian Shan, a total of 12 seismic profiles are provided (see location in Figures 1 and 4). Four of them $\left(\mathrm{AA}^{\prime}, \mathrm{BB}^{\prime}, \mathrm{CC}^{\prime}\right.$, and $\left.\mathrm{DD}^{\prime}\right)$ are situated in the Suganhu Basin, intersecting the fault systems in the Qilian Shan (Figure 5). Four seismic profiles ( $\mathrm{EE}^{\prime}, \mathrm{FF}^{\prime}, \mathrm{GG}^{\prime}$, and $\mathrm{HH}^{\prime}$ ) are situated along the southern flank of the Altyn Tagh Shan (western Qaidam Basin), adjacent to the ATF (Figure 6). Four seismic profiles ( $\mathrm{II}^{\prime}, \mathrm{JJ}^{\prime}, \mathrm{KK}^{\prime}$, and $\mathrm{LL}^{\prime}$ ) are situated in the northern Qaidam Basin (Figure 7). Seismic profile $\mathrm{GG}^{\prime}$ is situated in the western Qaidam Basin, adjacent to the ATF. Seismic profiles were interpreted using the SMT Kingdom software. To determine the age of reflectors shown on the seismic profiles, we follow previous studies (Cheng, Fu, et al., 2016; L. Wu et al., 2014; L. Wu et al., 2011; Xia et al., 2001; Yin, Dang, Zhang, et al., 2008) and assign the age of each boundary between the two formations by using the information obtained from drilling wells and regional seismic reflector correlation. The seismic data are in units of two-way travel time, and horizons in the seismic lines have been established by creating time-depth relationships and synthetic seismograms for the wells. This data processing is done by the Qinghai Oilfield Company, PetroChina. The age model is provided in the Table 1.

\subsection{Detrital Zircon Geochronology}

To document the source regions for the Mesozoic strata in the north-western Qilian Shan, two Jurassic samples were collected from a drilling well in the Suganhu Basin. We extracted zircon grains at the Chengxin Geology Service Co. Ltd., Langfang, China. To avoid sampling bias, zircon crystals (generally $>200$ grains) were mounted in epoxy resin without handpicking. Zircon crystals were then polished to obtain a smooth 

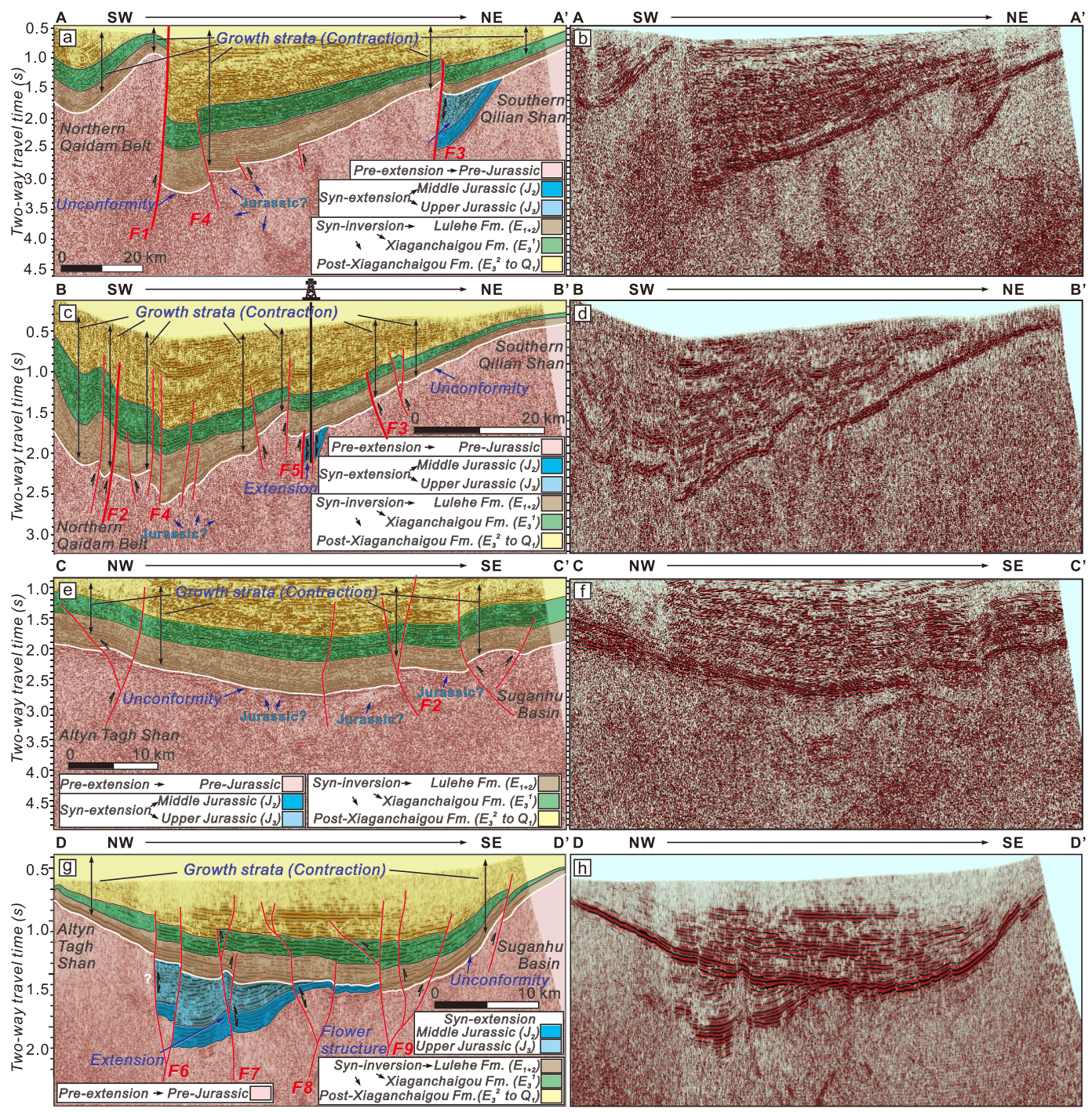

Figure 5. Seismic profiles in the Suganbu Basin. The locations of these profiles are shown in Figure 1c. (a, c, e, and g) Interpreted profiles. (b, d, f, and h) Uninterpreted profiles.

internal surface. To detect internal heterogeneities and allow for selecting target areas for isotopic dating, transmitted-light, reflected-light and cathodoluminescence (CL) images were taken at the Laboratory of Earth Surface Process and Environment, Nanjing University, and Key Laboratory of Orogenic Belts and Crustal Evolution, Peking University, respectively. Samples (ST-J2, ST-J3) were dated in the Laboratory of Earth Surface Process and Environment, Nanjing University, China, using a New Wave $193 \mathrm{~nm}$ laser ablation system and Agilent 7700x ICP-MS. The detailed analytical protocol followed (H. Zhang et al., 2016). A complete list of $\mathrm{U}-\mathrm{Pb}$ isotopic ages with errors and related raw data can be found in Table S1 in the supporting information.

\subsection{Heavy Mineral Analysis}

A total of 28 sandstone samples (ranging in age from Jurassic to Early Cenozoic) were collected from drilling well (Well 1) in the Qilian Shan for heavy mineral analysis (Figures 1 and 2). Heavy mineral separation and identification were carried out by the PetroChina, Qinghai Oilfield Company. The detailed heavy mineral analysis followed L. Fu et al. (2013), L. Li et al. (2015), and Z. Li et al. (2004). Authigenic and opaque minerals were excluded from the analyses. Detailed mineralogical data from the samples are given in Table S1. 

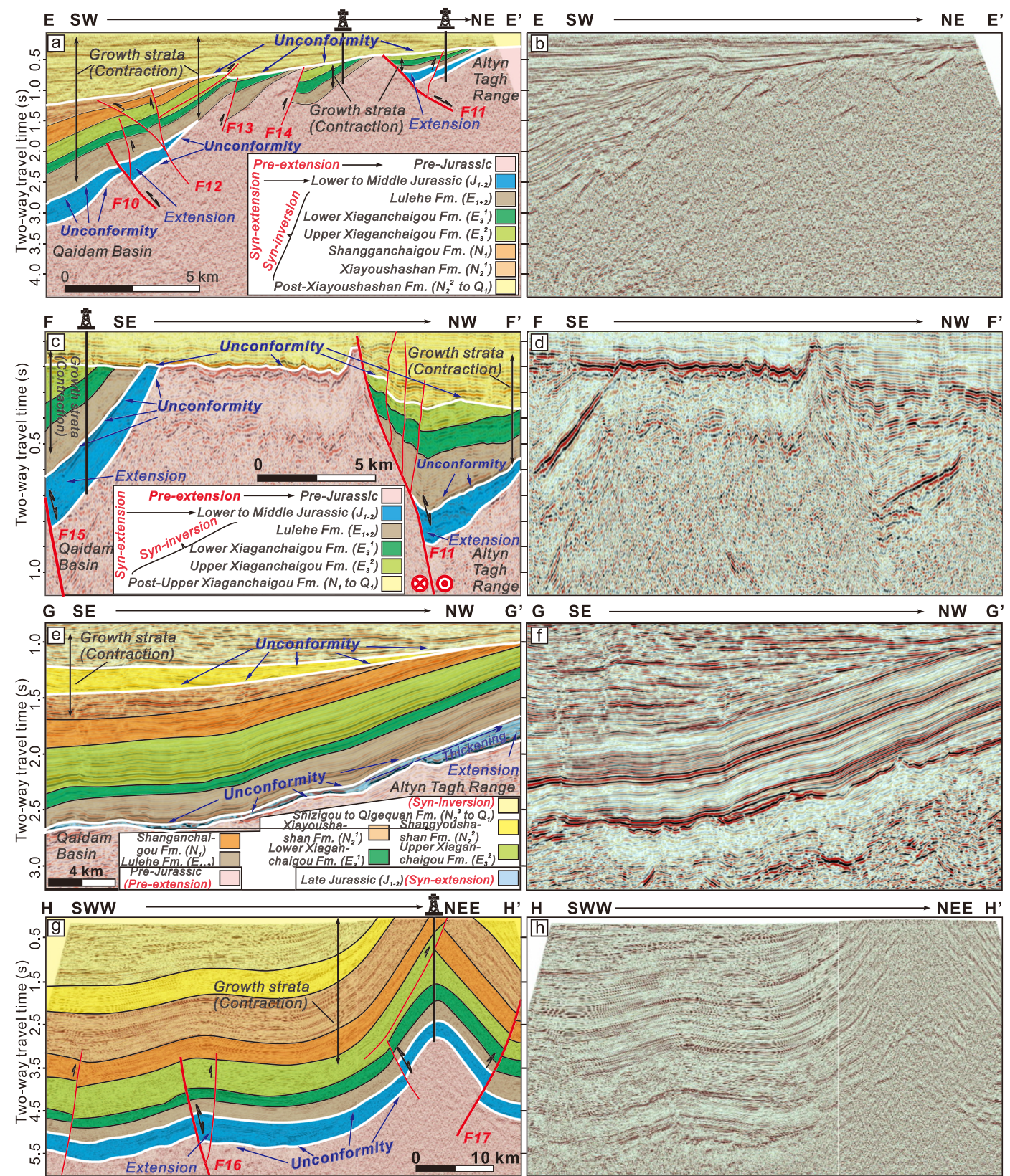

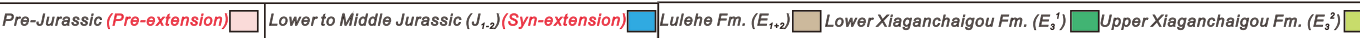

Shanganchaigou Fm. $\left(N_{1}\right) \quad \square$ Xiayoushashan $F m$. $\left(N_{2}^{1}\right) \square$ Shangyoushashan $F m .\left(N_{2}^{2}\right) \square$ Shizigou and Qigequan $F m$. $\left(N_{2}^{3}\right.$ to $\left.Q_{1}\right) \square \quad \square \quad$ (Syn-inversion)

Figure 6. Seismic profiles in the western Qaidam Basin, adjacent to the ATF shearing zone. The locations of these profiles are shown in Figures 1c and 4. (a, c, e, and g) Interpreted profiles. (b, d, f, and h) Uninterpreted profiles.

\section{Results}

\subsection{Isopach Maps of the Mesozoic Strata in the Qaidam Basin}

4.1.1. Early to Middle Jurassic Basin

The extent of the Early to Middle Jurassic Qaidam Basin was much smaller than its present size (Figure 4a), and can be divided into two subbasins (subbasin A and subbasin B in Figure 4a). Both subbasins are generally characterized by a NW-SE orientation of the isopachs.

Subbasin A is located in the northern Qaidam Basin, occupying an irregular ellipsoid-shaped area with an approximately $280-\mathrm{km}$ major axis and a $120-\mathrm{km}$ minor axis. The maximum subsidence point $(\sim 1,800 \mathrm{~m})$ is located in the junction area between the ATF shearing zone and the NQTB (Figure 4a), while the main 

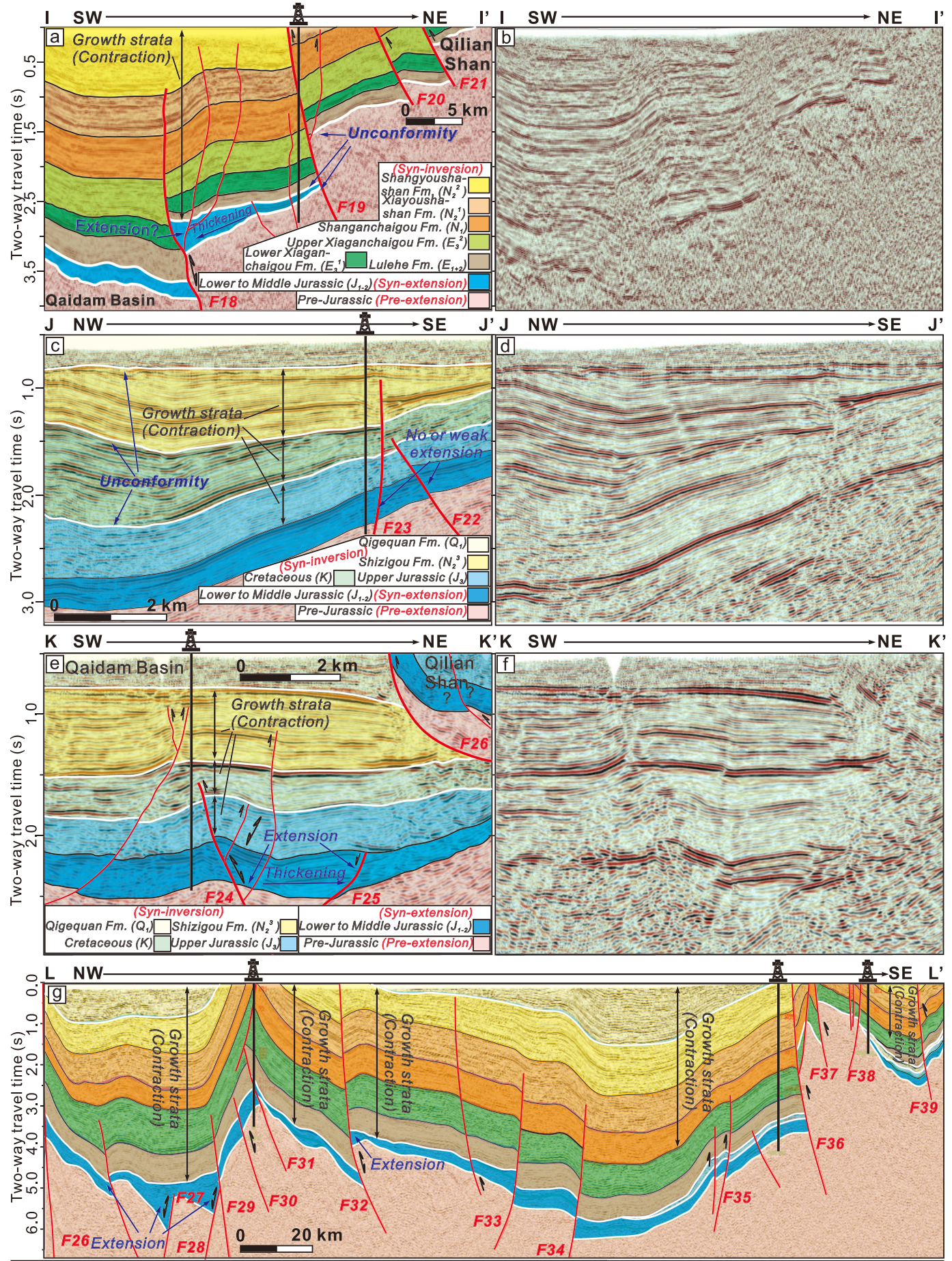

Pre-Jurassic (Pre-extension) $\square$ Lower to Middle Jurassic $\left(J_{1-2}\right)$ (Syn-extension) $\square$ Upper Jurassic $\left(J_{3}\right) \square$ Cretaceous $(K) \square$ Lower Xiaganchaigou and upper Xiaganchaigou $\mathrm{Fm} .\left(E_{3}{ }^{1}+E_{3}{ }^{2}\right) \square$ Shanganchaigou Fm. $\left(N_{1}\right) \square$ Xiayoushashan Fm. $\left(N_{2}{ }^{1}\right) \square$ Lulehe Fm. $\left(E_{1+2}\right) \square$ Shangyoushashan Fm. $\left(N_{2}{ }^{2}\right) \square$ Shizigou Fm. $\left(N_{2}{ }^{3}\right) \square$ Qigequan Fm. $\left(Q_{1}\right) \square \quad$ (Syn-inversion)

Figure 7. Seismic profiles in the northern Qaidam Basin. The locations of these profiles are shown in Figures 1c and 4. (a, c, e, and g) Interpreted profiles. (b, d, and f) Uninterpreted profiles.

depocenter zone (800-1,700 $\mathrm{m}$ ) lies along the northwest trending basin axis with its thickest portion located 60-70 km south of the present-day northern Qaidam Basin margin (Figure 4a). In addition, several smaller depocenters are scattered in subbasin A. 
Subbasin B is located in the eastern Qaidam Basin, forming an irregular polygonal area. Several subdepocenters are scattered, whereas the main depocenter zone is still located in the center of the subbasin (approximately $50 \mathrm{~km}$ away from the present-day northern margin of the Qaidam Basin; Figure 4b).

In addition to these two major sedimentation zones, Early to Middle Jurassic strata are sporadically exposed within the Altyn Tagh Shan (Cheng, Jolivet, et al., 2015; QBGMR, 1991; Sobel et al., 2001; Figure 4a). However, due to strong postdepositional deformation, the thickness of the deposits as well as their initial geometry are poorly constrained and need to be further documented (Figure 4a).

\subsubsection{Late Jurassic to Early Cretaceous Basin}

The most noticeable change from Late Jurassic to Early Cretaceous time is the appearance of a subbasin C in the southwestern Qaidam Basin adjacent to the ATF shearing zone. Subbasin C is still characterized by a NW-SE orientation of the isopachs. Despite scattered smaller depocenters, the main depocenter zone (over $500 \mathrm{~m}$ ) is located along the ATF (Figure 4b). The Late Jurassic to Early Cretaceous strata generally thicken toward the fault zone to the northwest and thin southeastward. Simultaneously, subbasin A becomes smaller. The remainder of the isopachs of subbasin A also trend NW-SE, with the depocenter zone (approximately $800 \mathrm{~m}$ ) located $\sim 5 \mathrm{~km}$ south of the present-day northern Qaidam Basin margin (Figure 4b).

To the east, subbasin B expands in an E-W direction toward the center of the Qaidam Basin and becomes deeper. The subbasin is still mainly characterized by a NW-SE orientation of the isopachs, although in the southwestern portion of the subbasin B local isopachs are NEE-SWW orientated.

\subsection{Seismic Profiles}

\subsubsection{Seismic Profiles in the Suganhu Basin, Across the SW Qilian Shan}

Seismic profiles $\mathrm{AA}^{\prime}$ (Figures 5a and $5 \mathrm{~b}$ ) and $\mathrm{BB}^{\prime}$ (Figures $5 \mathrm{c}$ and $5 \mathrm{~d}$ ) are SW-NE trending, extending from the front of the NQTB to the southern flank of the SQS (Figure 1c). On both seismic profiles, basement faults exert a major control on the distribution of the Jurassic strata. The Jurassic strata thicken toward fault F3 on section $\mathrm{AA}^{\prime}$ (Figures 5a and 5b) and thicken toward fault F5 on section $\mathrm{BB}^{\prime}$ (Figures 5c and 5d). Previous studies inferred that Jurassic strata might be present along fault F4 ( $M$ Zhang, 2012), although these are difficult to identify on our seismic profiles due to the presence of noise (Figures $5 \mathrm{a}$ and $5 \mathrm{~d}$ ). The Cretaceous sequence is missing and the Cenozoic Lulehe formation deposits unconformably overlie the Jurassic series (Figure 5). The Cenozoic strata are cut by a series of basement faults (including F1, F2, F3, and F4) forming block-like structures. In the hanging wall of fault F1, F2, F3, and F4, Cenozoic deposits thin toward the faults and form growth structures indicative of compressive deformation (Figures 5a and 5d). Both faults F3 and F5 dip southwest with a relative high dip angle $\left(60^{\circ}-80^{\circ}\right)$. A possible cause of faultward thickening of the Jurassic strata could be: the Jurassic strata were tilted NE side up due to the regional deformation; meanwhile or subsequently, the Jurassic strata were truncated by a steep-NE vergent thrust faults to the SW, these Jurassic strata were finally covered beneath an angular unconformity at the base of the Paleogene Lulehe formation strata. On the other hand, another possibility is that both steep F3 and F5 were tear faults which were active during the Jurassic. The shearing or strike-slip motions along the F3 and F5 led to a transtensional/extensional setting in the western part of Qilian Shan, which resulted in the thickening of the Jurassic strata toward the faults. The shearing or strike-slip motions along the F3 and F5 could be attributed to the faulting along the ATF, which largely transferred the sinistral displacement along the ATF into the Qilian Shan region (Cheng, Garzione, Jolivet, Guo, et al., 2019; Cheng, Jolivet, et al., 2015; Cheng, Jolivet, et al., 2016).

Seismic profiles $\mathrm{CC}^{\prime}$ (Figures 5e and 5f) and DD' (Figures 5g and 5h) are NW-SE trending, extending from the ATF shearing zone toward the center of the Suganhu Basin (Figure 1c). Previous studies inferred that Jurassic strata might occur in this region (M. Zhang, 2012), but they are difficult to identify on seismic profile $\mathrm{CC}^{\prime}$ due to the presence of noise (Figures 5e and 5f). On seismic profile $\mathrm{DD}^{\prime}$, parallel to $\mathrm{CC}^{\prime}$ at a distance of about $20 \mathrm{~km}$, the Jurassic strata are well identified, thickening toward the southeast dipping high-angle $\left(60^{\circ}-80^{\circ}\right)$ basement faults (F6 and F7), again confirming the occurrence of Jurassic transtensional/extensional structures in that region. The Cretaceous series are missing, and the Jurassic normal faults were inverted during the deposition of the Lulehe formation, leading to the formation of growth structures (Figures $5 \mathrm{~g}$ and $5 \mathrm{~h}$ ). The interpreted fault pattern is shown in Figure 1c. We suggest that all those 
faults (F1 to F9) are linked to the ATF shearing zone to the north and might undergo sinistral or dextral strike slip motions in addition to dip slip motions.

\subsubsection{Seismic Profiles in the Western Qaidam Basin (Along the ATF)}

Seismic profiles $\mathrm{EE}^{\prime}$ and $\mathrm{FF}^{\prime}$ are situated in the southern flank of Altyn Tagh Shan, adjacent to the junction area between the ATF zone and the NQTB (Figures 1c and 4). Seismic profile EE' (Figures 6a and $6 \mathrm{~b}$ ) trends SW-NE, extending from the Qaidam Basin toward the ATF. Seismic profile FF $^{\prime}$ (Figures $6 \mathrm{c}$ and $6 \mathrm{~d}$ ) trends NW-SE, extending from the NQTB toward the ATF. On section EE', the Early to Middle Jurassic strata can be identified in two areas thickening toward the basement faults (F10, F11, and F12). These faults dip northeast with a dip angle of $60^{\circ}-80^{\circ}$, rooting into the ATF. We thus interpret these faults as normal faults indicating an extensional/transtensional regime during the Jurassic. Similar syndepositional structures can also be observed on section $\mathrm{FF}^{\prime}$ where the Early to Middle Jurassic strata thicken toward the southwest dipping basement faults (F11 and F15). The Cretaceous deposits are again missing on both sections and the Cenozoic series unconformably overlie the Early to Middle Jurassic strata (Figures 6a-6d). The Early Cenozoic strata are dissected by several basement faults and taper toward the faults, forming growth strata in the hanging wall of those faults (F12, F13, and F14). Similarly to the Suganhu Basin, the preexisting Jurassic extensional/transtensional faults (F10, F11, F12, and F15) have been inverted during Cenozoic contractional deformation. In addition, an unconformity between the Miocene Xiayoushashan formation and the post-Xiayoushashan formation can be identified, likely suggesting a significant tectonic deformation and/or regional erosion during the Late Neogene (Figures 6a-6d). These faults, especially F11 and F15, are probably linked to the ATF system. Thus, we interpret that these faults may have undergone sinistral or dextral strike slip motions during the Cenozoic or even as early as the Mesozoic.

The NW-SE trending seismic profile $\mathrm{GG}^{\prime}$ is situated in the northwestern part of the SW Qaidam Basin, extending from the Qaidam Basin to the ATF (Figures 1 and 4c). In this section, the Late Jurassic strata thicken toward the ATF. Previous stratigraphy, sedimentology, and low-temperature thermochronology studies revealed that the Altyn Tagh Range had not been largely exhumated during the Early to Middle Jurassic, indicating limited topography features (topography load) in the Altyn Tagh Range (Marc Jolivet et al., 1999; Meng et al., 2001; Ritts \& Biffi, 2000). These studies further attribute the thickening of the Jurassic strata toward the ATF to the sinistral shearing or strike-slip faulting along the ATF. Although profile GG' fails $^{\prime}$ to show the ATF, we, therefore, interpreted the northward thickening of the Early to Middle Jurassic strata as growth strata that demonstrate the syndepositional faulting along the ATF and indicate an extensional/transtensional tectonic setting. The Cenozoic strata taper toward the ATF forming growth strata (Figures 6e and 6f), indicative of regional compression. Four unconformities (between the Late Jurassic strata and the underlying basement rocks, between the Lulehe formation and the Late Jurassic strata, between the Xiayoushashan formation and Shangyoushashan formation, and between the Shangyoushashan formation and post-Shangyoushashan formation strata) can be identified (Figures 6e and 6f), indicating several episodes of tectonic deformation and associated erosion.

The NE-SW oriented seismic profile $\mathrm{HH}^{\prime}$ is parallel to the ATF and runs from the western Qaidam Basin to the joint area between the ATF system and the NQTB (Figures 1c and 4). The Early to Middle Jurassic strata thicken toward the high-angle $\left(60^{\circ}-80^{\circ}\right)$ faults (e.g., F16) again presumably illustrating crustal transtension/extension during the Jurassic (Figures $6 \mathrm{~g}$ and $6 \mathrm{~h}$ ). Later, these Early to Middle Jurassic extensional faults were inverted during the Cenozoic tectonic phase and created a series of growth strata that taper toward the faults (F16). The Cretaceous strata are still missing in this region. The Early to Middle Jurassic strata unconformably underlie the Cenozoic strata and unconformably overlie the basement rocks (Figures 6g and 6h).

4.2.3. Seismic Profiles in the Northern Qaidam Basin, Along the Southern Flank of the Qilian Shan Seismic profile II' is oriented NE-SW and situated in the western part of the northern Qaidam Basin, running from the basin to the NQTB (Figures 1c and 4) and intersecting the fault systems that affect the northern Qaidam Basin. The tectonic pattern of this section is characterized by several steeply NE dipping $\left(50^{\circ}-70^{\circ}\right)$ faults $(\mathrm{F} 18, \mathrm{~F} 19, \mathrm{~F} 20$, and F21) defining a step-like structure. The Cretaceous strata are missing whereas the Early to Middle Jurassic strata are only preserved in the hanging wall and footwall of fault F18. The Early to Middle Jurassic series in the hanging wall thickens toward the faults (F18), whereas the overlapping Cenozoic series in the hanging wall gently thins toward the faults (Figures 7a and 7b). Again, 
these growth structures may suggest that the Early to Middle Jurassic transtensional/extensional faults were inverted during the Cenozoic contraction. Two unconformities (the Early to Middle Jurassic strata/the underlying basement rocks; the Early to Middle Jurassic strata/overlying Cenozoic series), corresponding to tectonic deformation and/or surface erosion are visible once again (Figures $7 \mathrm{a}$ and $7 \mathrm{~b}$ ).

Two short seismic profiles, section $\mathrm{JJ}^{\prime}$ and $\mathrm{KK}^{\prime}$, are situated in the eastern part of the northern Qaidam Basin. Seismic profile JJ' (Figures 7c and 7d) is trending NW-SE, parallel to the NQTB, while seismic profile $\mathrm{KK}^{\prime}$ is trending NE-SW (Figures 7e and 7f), extending from the Qaidam Basin toward the NQTB (Figures 1c and 4). On both sections, Early to Middle Jurassic, Late Jurassic, Early Cretaceous, and Cenozoic strata can be identified. The Early to Middle Jurassic deposits gently thicken toward the NE and SW dipping faults (F22, F23, F24, and F25), potentially indicating normal components on those faults. Yet the Late Jurassic to Early Cretaceous strata taper toward these same faults, suggesting tectonic inversion as early as Late Jurassic (Figures 6c-6f). In addition, the Early Cenozoic Lulehe, Lower Xiaganchaigou, upper Xaaganchaigou, Shangganchaigou, Xiayoushashan, and Shangyoushashan formations are missing. Growth strata are well developed in the Late Neogene Shizigou formation, indicating Late Cenozoic compression (Figures 6c-6f). Similarly to the other profiles, four unconformities (Early to Middle Jurassic strata/underlying basement rocks, Early Cretaceous strata/Late Jurassic strata, Shizigou formation/Early Cretaceous strata, and Qigequan formation/Shizigou formation) can be observed (Figures 6c-6f).

Seismic profile LL' is a long NW-SE trending section, running from the southern flank of the Altyn Tagh Shan (western part of the northern Qaidam Basin) to the eastern part of the northern Qaidam Basin (Figures 1c and 4). Both the Mesozoic and the overlying Cenozoic deposits are cut by a series of basement faults. The Early and Middle Jurassic strata are developed throughout the section, while the Late Jurassic and the Cretaceous strata only developed in the eastern part of this section (Figure $7 \mathrm{~g}$ ). In particular, the Early to Middle Jurassic strata generally thicken toward the NW dipping high-angle $\left(50^{\circ}-70^{\circ}\right)$ faults in the western part of the section (see F26-F28 in Figure 7g), indicating a transtension/extension setting. However, in the eastern part of the section, the Early to Middle Jurassic strata either thicken or thin toward the high-angle faults (see F33, F36, and F39 in Figure 7g and see F34 and F35 in Figure 7g). We thus interpret the Early to Middle Jurassic basin located in the western part of this section as a pull-apart basin or a transtension zone related to the strike-slip faulting along the ATF shearing zone. On the other hand, the Early to Middle Jurassic basin located in the eastern part of this section was a transpressional or transtensional zone probably controlled by eastward crustal motion along the ATF toward the Qilian Shan/northern Qaidam Basin (Cheng, Jolivet, et al., 2015; Cheng, Jolivet, et al., 2016; Figure 10b). The Late Jurassic to Early Cretaceous as well as the overlying Cenozoic strata thin toward the various faults forming growth structures (see F39 in Figure 7g), again suggesting fault inversion occurring as early as Late Jurassic and persisting during the Late Mesozoic-Cenozoic.

\subsection{Zircon U-Pb Geochronology Results}

Samples ST-J2 and ST-J3 are Jurassic sediments obtained from drill cores in the Suganhu Basin (Figure 1). The zircon crystals in sample ST-J2 show euhedral shapes, with an average size ranging between 50 and 200 $\mu \mathrm{m}$. Most of these crystals ( $90 \%$ ) display distinct oscillatory zoning on CL images (Figure 8d), pointing to a predominantly magmatic origin (Corfu et al., 2003; Hanchar \& Rudnick, 1995). The Th/U ratios vary from 0.12 to 1.68 (Figure 8c), again indicative of the magmatic origin of the zircons (Hoskin \& Ireland, 2000). Among the 110 analyzed zircons, $101 \mathrm{U}-\mathrm{Pb}$ ages with discordance degree $<10 \%$ were obtained (Figure 8b). The U-Pb ages range from 2,587 to $237 \mathrm{Ma}$ with a predominant single peak at approximately $445 \mathrm{Ma}$, a secondary peak at approximately $808 \mathrm{Ma}$, and few Neoarchean to Paleoproterozoic ages distributed between 2,587 and 1,876 Ma (Figure $8 \mathrm{~h})$. The zircon grains in sample ST-J3 are large (80-280 $\mu \mathrm{m}$ ) with euhedral to abraded shapes. The large majority of crystals (>95\%) display distinct oscillatory zoning in CL (Figure 8e), suggesting predominance of magmatic zircons (Corfu et al., 2003; Hanchar \& Rudnick, 1995). The Th/U ratios vary from 0.32 to 1.57 (Figure 8c), again confirming a magmatic source (Hoskin \& Ireland, 2000). Among the 110 analyzed crystals, 102 acceptably concordant ages were obtained (Figure $8 \mathrm{a}$ ). The U-Pb ages vary from 2,482 to $261 \mathrm{Ma}$, with a significant unimodal age peak at approximately $445 \mathrm{Ma}$, a minor age peak at approximately $797 \mathrm{Ma}$, and a number of Paleoproterozoic to Mesoproterozoic ages spread between 2,484 and 1,514 Ma (Figure 8g). 


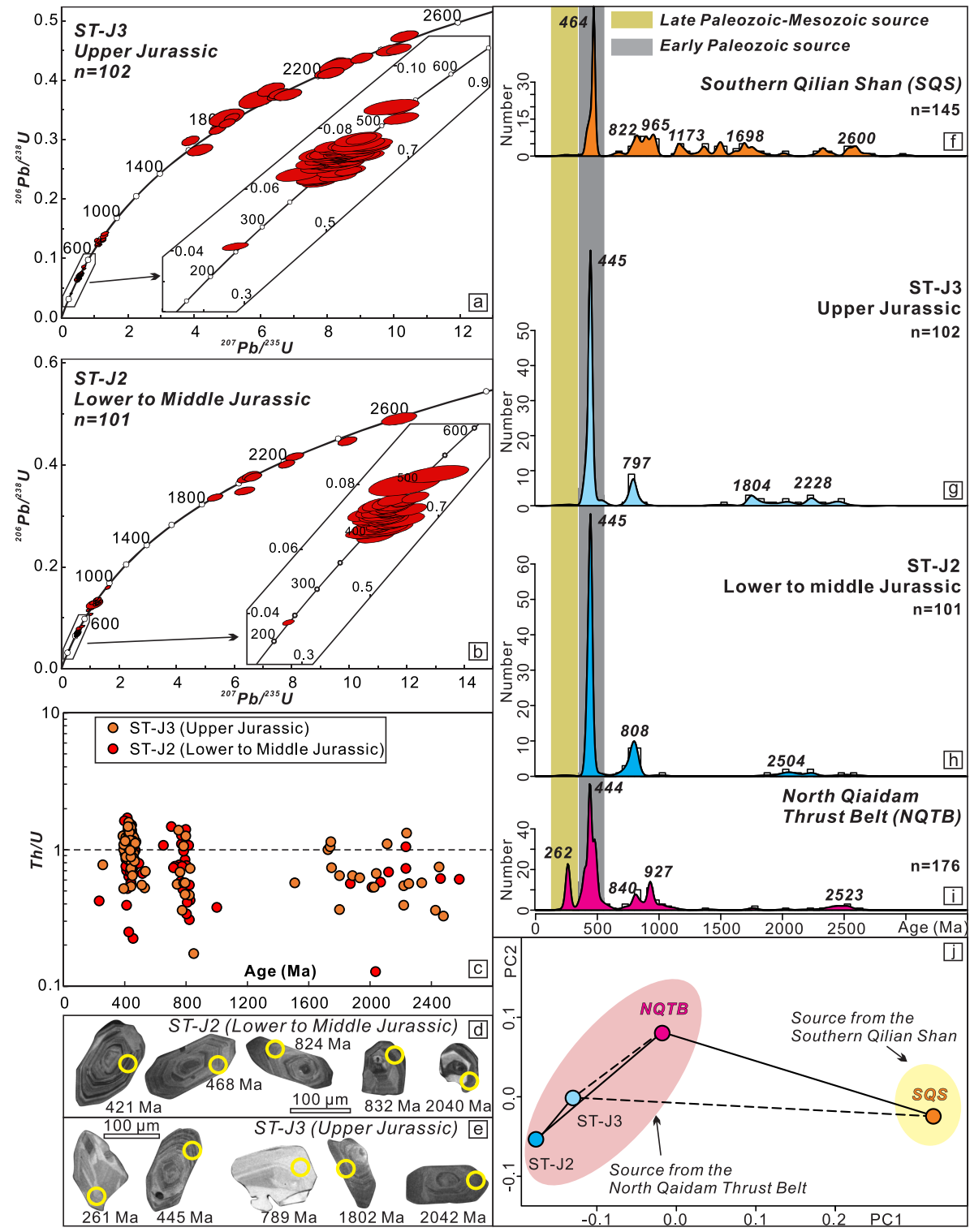

Figure 8. ( $\mathrm{a}$ and $\mathrm{b}$ ) The $\mathrm{U}-\mathrm{Pb}$ concordia diagrams for zircon grains of the Late Jurassic sandstone sample and Early to Middle Jurassic sandstone samples, respectively. (c) U-Pb age of analyzed zircons versus $\mathrm{Th} / \mathrm{U}$ ratios. (d and e) The representative CL images of zircons from the two sandstone samples, respectively. (f and i) The relative probability plot of granitoid pluton ages in the southern Qaidam Basin (SQS) and the North Qaidam Thrust Belt (NQTB), respectively. The U-Pb age data set is mainly from Cheng et al. (2017). ( $\mathrm{g}$ and $\mathrm{h}$ ) The zircon U-Pb age cumulative probability distribution for the Late Jurassic sandstone and the Early to Middle Jurassic sandstone, respectively. The ages, in Ma, are indicated on the horizontal axis. (j) Multidimensional scaling map uses the Kolmogorov-Smirnov (KS) statistic for detrital zircon U-Pb data sets (Vermeesch, 2013), showing the distinct signature of northern Qaidam terrane and southern Qilian Shan source regions. Axes are in dimensionless "K-S units" $(0<\mathrm{KS}<1)$, showing "distance" between samples. Principal component analysis is used. PC1 and PC2 refer to the two principal components. Solid lines and dashed lines connect samples with their "closest" and "second closest" neighbors, respectively. Note that zircon age distributions from both the Late Jurassic (ST-J3) and Early to Middle Jurassic sample (ST-J2) are statistically similar with those of granitoid plutons from the SQS, different from with those of granitoid plutons from the NQTB.

\subsection{Heavy Mineral Assemblages}

In order to compare heavy mineral assemblages, volume percent of each heavy mineral species was calculated for each sample and zircon-tourmaline-rutile (ZTR) index were used (Figure 9; Hubert, 1962). The heavy mineral suites of the all the Jurassic and Early Cenozoic samples mainly consists of hornblende, garnet, and zircon associated with few sphene, termolite, tourmaline, and zoisite. Despite enrichment of 


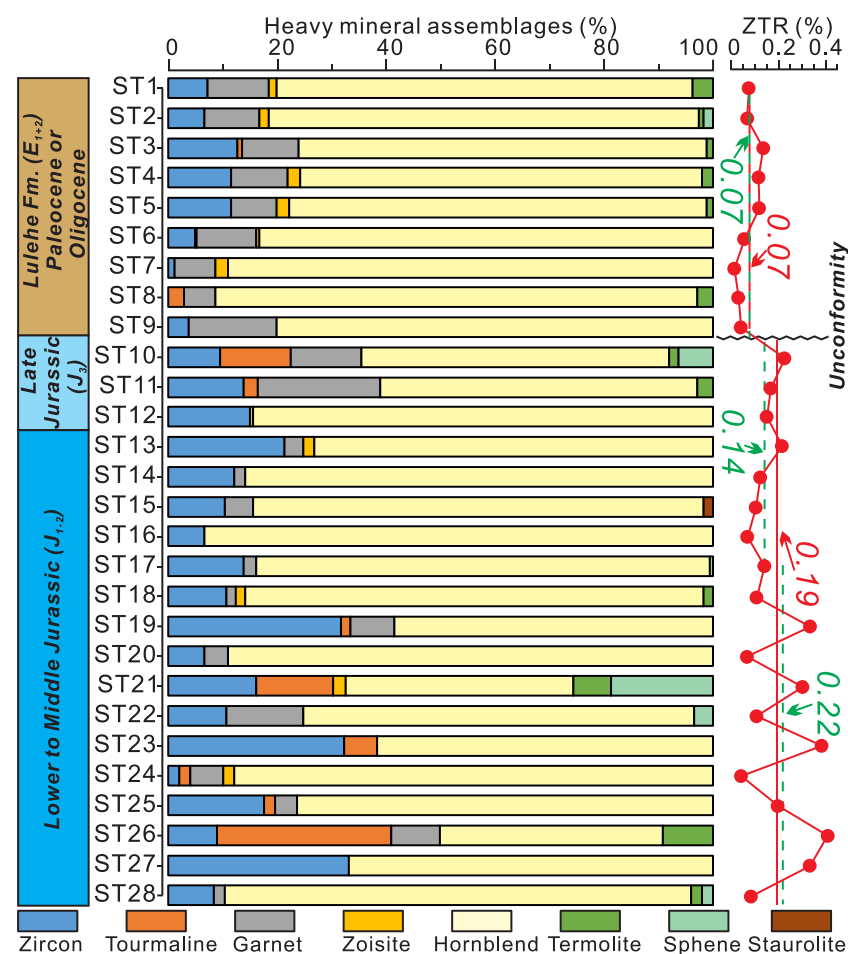

Figure 9. Heavy mineral assemblages of Jurassic and Early Cenozoic samples in the Suganu Basin. Note that zircon-tourmaline-rutile (ZTR) index dramatically decrease during the interval between Late Jurassic and Early Cenozoic, indicating intensive deformation at that time. Note that the two red numbers ( 0.19 and 0.07$)$ refer to the mean ZTR value of Jurassic samples and Paleogene samples, respectively. The three green numbers $(0.22,0.14$, and 0.07 ) refer to the mean ZTR value of samples ST18 to ST28, samples ST10 to ST17, and samples ST1 to ST9, respectively. unstable minerals (over $70 \%$ of total on average), each sample carries distinctive heavy mineral signatures (Figure 9).

In the samples from the lower part of the Early to Middle Jurassic succession (sample ST28 to sample ST18), the mean proportion of hornblende, garnet, sphene, termolite, and zoisite is $62 \%, 6 \%, 6 \%, 5 \%$, and $2 \%$, respectively. The total proportion of stable zircon and tourmaline largely fluctuates between $4 \%$ and $35 \%$, while the ZTR index largely fluctuates with its mean value around 0.22 (Figure 9).

In the samples from the upper part of the Early to Middle Jurassic succession (sample ST17 to sample ST10), the total proportion of the zircon and tourmaline becomes slightly more constant, varying between $6 \%$ and $21 \%$. The proportion of garnet generally increases upsection while the proportion of hornblende decreases in parallel. The proportions of sphene, termolite, zoisite, and staurolite are negligible in most samples. The amplitude of variation of the ZTR index curve becomes stable, with an average value of 0.14 (Figure 9).

From the Late Jurassic to the first Early Cenozoic samples (sample ST10 to sample ST7), the proportion of hornblende gradually increases (from 52\% in sample ST10 to 80\% in sample ST7), while the total proportion of zircon and tourmaline decreases (from $21 \%$ in sample ST10 to $1.1 \%$ in sample ST7). Since then, the proportion of hornblende slightly decreases and varies between $70 \%$ and $81 \%$, while the total proportion of zircon and tourmaline increases and varies between $5 \%$ and $13 \%$. In all the Cenozoic samples, the proportion of garnet is relatively stable with an average value of $10 \%$, while the sphene, termolite, zoisite, and staurolite are still negligible in most samples, with proportions fluctuating between $0 \%$ and $4 \%$. The ZTR index during this time interval continuously decreases with an average value of 0.07 (Figure 9).

\section{Discussion}

\subsection{Provenance of the Jurassic Deposits in the Qilian Shan}

The SQS and NQTB are the two potential source regions likely to provide zircons to the Suganhu Basin during the Jurassic (Bovet et al., 2009; Meng \& Fang, 2008; Yin, Dang, Wang, et al., 2008). We first compiled the zircon $\mathrm{U}-\mathrm{Pb}$ ages available from basement rocks of these two regions (Figures $8 \mathrm{f}$ and $8 \mathrm{i}$ ). We then compare the zircon $\mathrm{U}-\mathrm{Pb}$ ages distribution of the Jurassic samples with basement data from the SQS and the NQTB in order to reveal the source variation from the Early Jurassic to Late Jurassic. In order to understand the similarities/differences between the zircon U-Pb distribution of individual samples and the zircon U-Pb pattern of the basement of the SQS and the NQTB, we constructed a multidimensional scaling (MDS) map (Figure 8j). This map was developed to create a spatial visualization and quantitatively determine the misfit between age distributions using the Kolmogorov-Smirnov test as the dissimilarity measure (Vermeesch, 2013).

The zircon $\mathrm{U}-\mathrm{Pb}$ ages from granitic basement of the SQS region can be generally divided into four populations with a major peak at approximately $470 \mathrm{Ma}$ and three additional populations at approximately 2,710-2,260, approximately 1,870-1,130, and approximately 1,030-740 Ma, respectively (Figure 8f). Differing from the SQS, the zircon U-Pb age spectrum of the NQTB basement is characterized by a noticeable decrease in Archean-Paleoproterozoic ages (from over 25\% in the SQS to less than 10\% in the NQTB) and a significant increase in the Late Paleozoic-Mesozoic ages (secondary peak age at $240 \mathrm{Ma}$; from less than $1 \%$ in the SQS to around 15\% in the NQTB). In addition, Early Paleozoic granitoid plutons are widely spread in the NQTB, with a peak zircon U-Pb age at $444 \mathrm{Ma}$, whereas some Neoproterozoic plutons are also present with zircon $\mathrm{U}-\mathrm{Pb}$ ages ranging between $\sim 1,080$ and $\sim 740 \mathrm{Ma}$ (Figure $8 \mathrm{i}$ ).

As displayed in Figure 8j, zircon age distributions of both the Early to Middle Jurassic (ST-J2) and Late Jurassic (ST-J3) samples from the Suganhu Basin are statistically different from those of the granitic 


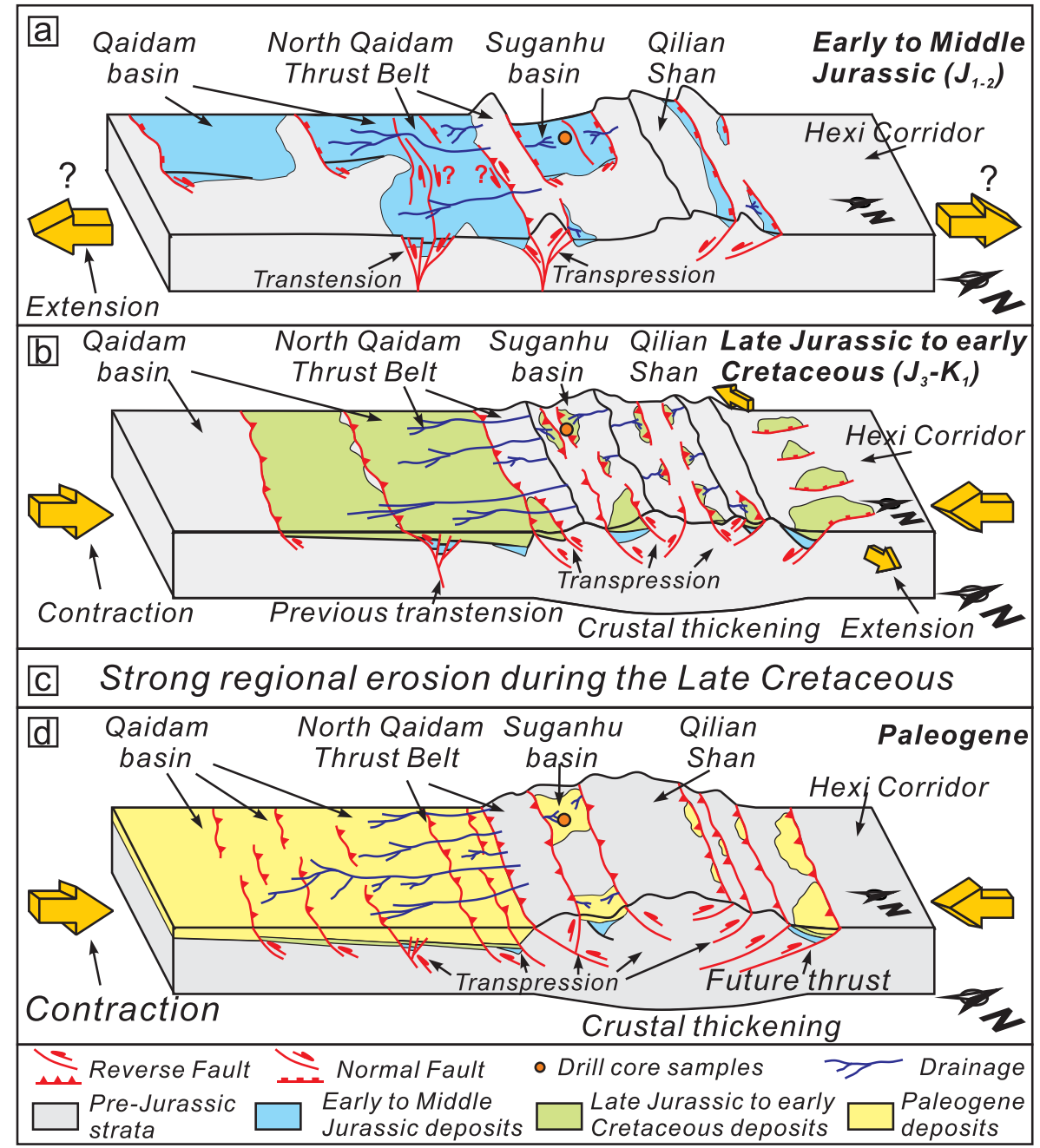

Figure 10. Scenarios for the tectonic inversion in the Qilian Shan and the northern Qaidam Basin from the Jurassic to Paleogene. See Figure $1 b$ for the location. The information of Late Jurassic to Early Cretaceous extension in the Hexi Corridor is based on the work of $S$ Chen et al. (2014). Note that the eastern part of the northern Qaidam Basin was characterized by transpressional and transtensional tectonics during the Mesozoic. Since the Early Cenozoic, it was completely inverted under a N-S or NE-SW oriented compression.

basement in the SQS. However, they are similar to that of basement intrusions in the NQTB, indicating that the NQTB served as a dominant source of detrital material for the Suganhu Basin during the Jurassic. This suggests that the Late Paleozoic-Mesozoic plutons were not exhumed in the NQTB in the Jurassic. Given that different vintages of plutons are usually exhumed in sequence, if few Early Paleozoic, Mesoproterozoic, and Paleoproterozoic basements in the SQS were exhumed during the Jurassic, the SQS could also be the source of detrital materials for the Suganhu Basin. On the other hand, the significant increase in the proportion of hornblende (from 52\% in sample ST10 to 80\% in sample ST7), the noticeable decrease of the total proportion of zircon and tourmaline (from $21 \%$ in sample ST10 to $1.1 \%$ in sample ST7), and the decrease in the ZTR index (from 0.19 on average in the Jurassic samples to 0.07 on average in the Early Cenozoic Lulehe formation samples) indicate modification of the local paleogeography and drainage system in this region (Figure 9). This conclusion is consistent with the obvious regional unconformity between the Jurassic and Paleogene strata in the Suganhu Basin shown on seismic sections (Figure 5). Thus, we infer that a significant tectonic deformation phase occurred during the Cretaceous. This event modified the local paleogeography and drainage system in the Qilian Shan-north Qaidam region. 


\subsection{Tectonic Inversion in the Qilian Shan and Qaidam Basin: From Early-Middle Jurassic Extension to Late Jurassic-Cenozoic Contraction}

The seismic profiles described above display direct evidence of Jurassic extension in the western part of the Qilian Shan (Suganhu Basin; Figure 5). In particular, Early to Middle Jurassic normal faulting can be identified in the regions adjacent to the ATF shearing zone, including the western part of both the Qilian Shan (Figure 5) and the northern Qaidam Basin (Figures 6a-6d), as well as in the western Qaidam Basin (Figures 6e-6h). However, in regions away from the ATF (e.g., the eastern part of the northern Qaidam Basin; Figures 7c-7g), the Early to Middle Jurassic sedimentation is controlled by both extensional and contractional tectonics depending on the precise location (Figure 7). This kinematic pattern suggests that the extensional/transtensional basins that developed nearby the ATF during the Early to Middle Jurassic were pull-apart basins or extensional/transtensional relay zones that related to sinistral strike-slip movement along the ATF shearing zone. This deformation was mainly accommodated by extension in the northern Qaidam Basin and the Qilian Shan, as the tectonic lineaments branching on the ATF were active as normal faults (Cheng, Jolivet, et al., 2015; Cheng, Jolivet, et al., 2016). Locally, the strike-slip component associated with the largest faults likely induced transpression in a similar fashion as the relay zones in the ATF corridor. This inference is not only in good agreement with the extensional setting model based on field investigation, seismic profile interpretation, and provenance analysis (L. Wu et al., 2011; Yin, Dang, Zhang, et al., 2008; Yu et al., 2017) but also explains the presence of localized contractional tectonics in the eastern part of the northern Qaidam Basin (Ritts \& Biffi, 2001).

The Late Jurassic strata along the ATF shearing zone (Figures 5, 6e, and 6f) thicken toward to the faults (Figures 6a-6d), while the Late Jurassic strata that are distributed far away from the ATF shearing zone (eastern part of the northern Qaidam Basin) are characterized by a relatively stable thickness or even tapering toward the faults (Figures $7 \mathrm{~g}$ and $7 \mathrm{~h}$ ). We thus infer that the continued strike-slip motion along the ATF during the Late Jurassic maintained extension within and nearby ATF zone. However, regions distant from the ATF (from the ATF toward the Qilian Shan/northern Qaidam Basin) were instead evolving in a transpressional or contractional setting.

The growth strata that initiated during the Cretaceous in the eastern part of the northern Qaidam Basin are well-developed and record the Early Cretaceous transition to contractional deformation in this region (Figures 7c-7g). In contrast, as shown on the isopach map and seismic profiles (Figures $4 \mathrm{~b}$ and $6 \mathrm{c}-6 \mathrm{f}$ ), the Cretaceous strata distributed in the western Qaidam Basin thicken toward the ATF shearing zone, which would be either attributed to the extension or transtension along the ATF shearing zone or the exhumation of the Altyn Tagh Range that formed as a topographic load and caused the local flexural subsidence in the western Qaidam basin.

Since the Cenozoic, both the Qilian Shan and the Qaidam Basin have experienced several stages of contractional deformation. This inference is evidenced by the variation of heavy mineral compositions as described above (Figure 9), as well as by the Early Cenozoic initiation of growth strata and angular unconformities displayed on the seismic profiles (Figures 5-7). The main reverse faults in the Qilian Shan and northern Qaidam Basin also present a nonnegligible strike-slip component accommodating the eastward crustal extrusion of the Qaidam Basin-Northern Tibet region (Allen et al., 2017; Cheng et al., 2019; Cheng, Guo, et al., 2015; Cheng, Jolivet, et al., 2016).

These Jurassic to Cretaceous deformation events in the Qilian Shan and northern Qaidam Basin as well as along the ATF shearing zone are chronologically consistent with the coeval tectonic cooling events evidenced by previous fission track and ${ }^{40} \mathrm{Ar} /{ }^{39} \mathrm{Ar}$ thermochronology studies (Arnaud et al., 2003; Chen et al., 2003; Delville et al., 2001; M. Jolivet et al., 2001; Li et al., 2006; Liu et al., 2007; Pan et al., 2013; Qi et al., 2016; Sobel et al., 2001; Y. Wang et al., 2005). As shown in the isopach map, a majority of Jurassic strata are currently distributed in the northern Qaidam basin, especially in the eastern part of the basin, with their strike parallel to the Qilian Shan (Figure 4). However, previous studies have revealed that the Qaidam basin might have experienced crustal deformation since India-Asian collision initiated at the Early Cenozoic, characterized by the eastward crustal extrusion in the southern Qilian Shan and northern Qaidam basin (Cheng et al., 2017; Cheng, Jolivet, et al., 2015; Cheng, Jolivet, et al., 2016). We thus suggest that the Jurassic strata, currently in the northern Qaidam basin, have been overprinted by 
the Cenozoic eastward crustal extrusion and should be much closer to the Altyn Tagh Fault during the Jurassic. The faulting along the ATF and the transpressional/transtensional tectonics that related to the ATF drove the subsidence of the Jurassic Qaidam basin.

\subsection{Potential Mechanism Driving the Early Jurassic Intracontinental Extension/Transtension in North Tibet}

It is widely acknowledged that North Tibet has evolved into intracontinental geodynamic setting since the final closure of the Paleo-Tethys ocean during the Late Paleozoic-Early Mesozoic (Hendrix, 2000; Hendrix et al., 1992; Jolivet, 2015; Roger et al., 2010; Vincent \& Allen, 1999) and that this region was subsequently affected by the collision between the Lhasa and the Qiangtang terranes during latest Jurassic to earliest Cretaceous time (Coward et al., 1988; Harris et al., 1988; Kidd et al., 1988). Geologists generally attribute the Mesozoic extension in North Tibet to the far-field effects of Gondwana-derived block collisions along the southern edge of Asia at that time (Vincent \& Allen, 1999; L. Wu et al., 2011). However, no real attempt to describe the associated continental-scale stress field has been made and similar mechanisms are put forward to explain contemporaneous or nearcontemporaneous compression.

In order to explain extension, recent studies proposed that the North Tibet region, including the Qilian Shan and the Qaidam Basin, was in a postcollisional setting following the orogenic event induced by the closure of the Palaeo-Tethys Ocean and the docking of the Qiangtang block (Yu et al., 2017). Although postcollisional granites in the Eastern Kunlun Shan and eastern Qaidam Basin have been reported (X Chen et al., 2012; X Chen et al., 2015) together with some Middle Jurassic age detrital zircons in the northern Qilian Shan (Cheng, Garzione, Jolivet, Wang, et al., 2019), no Early to Middle Jurassic plutonic nor volcanic rocks have yet been found in the areas north of the Eastern Kunlun Shan, indicating a lack of Jurassic magmatism in the Qilian Shan-Qaidam Basin region (Cheng et al., 2017; Yin \& Harrison, 2000). Therefore, we should be cautious about making the inference that postcollisional extension, which is concerned with the subduction and closure of the Palaeo-Tethys Ocean along the Kunlun-Anyemaqen suture zone in the Eastern Kunlun Shan to the south, could sustain to the Early to Middle Jurassic time and dictate the Mesozoic tectonics in the Qilian Shan and Qaidam Basin to the north.

In the Songpan-Ganzi terrane, south of the Kunlun range, the Late Permian to Middle Triassic molasses, corresponding to sedimentation in the eastern branch of the closing Paleo-Tethys ocean are strongly deformed. However, they are unconformably covered by slightly folded Late Triassic deposits suggesting that the oceanic closure and collision between Qiangtang and Kunlun terranes had nearly ended by that time (Calassou, 1994; Roger et al., 2010). The docking and the final amalgamation of the Qiangtang block to the Eurasian continent resulted in very limited deformation and the generated stress would not trigger the Mesozoic tectonism in the Qilian Shan and Qaidam Basin. To the north, the scissors-like Permian to Cretaceous closure of the Mongol-Okhotsk ocean, located several thousands of kilometers to the north, produce only limited deformation in Siberia and Mongolia.

In spite of alteration by the subsequent Early Cenozoic tectonic deformation, field observation (Cheng, Guo, et al., 2015; Ritts \& Biffi, 2000, 2001; Edward R. Sobel et al., 2001) and subsurface data (including the seismic reflections and isopach map) clearly show that the Early to Middle Jurassic strata are largely distributed along the Paleozoic inherited faults, especially the ATF shearing zone (Figures 1 and 6). Similar stratigraphic distribution of Early to Middle Jurassic series can also be observed along the Talas Fergana Fault (Morin et al., 2018; Sobel, 1999), in the Kazakh and Turan platform (Thomas et al., 1999), in the pre-Caspian Basin further to the west (Moseley \& Tsimmer, 2000) and even in the Hexi Corridor, northeast of the Tibetan Plateau (S. Chen et al., 2014). Following the model proposed by Morin et al. (2018), we propose that, in the absence of major collisional event during Early to Middle Jurassic period, the Early to Middle Jurassic strike-slip motion along the ATF and the associated regional extension may have responded to far-field effects of subduction processes along the southern edges of Eurasia. The associated stress-field reactivated the major tectonic structures inherited from the Paleozoic (Figure 10). 


\section{Conclusions}

A better understanding of the Mesozoic tectonism in the Qilian Shan and Qaidam Basin provides significant insights into the growth mechanism of the northern portion of the Tibetan Plateau in the Cenozoic. The geophysical, sedimentological, and geochronological data presented in this work document the following conclusions:

1. The Northern Qaidam Thrust Belt served as the major source of clastic materials for the Suganhu Basin during the Jurassic before regional tectonic deformation initiating during the Cretaceous strongly modified the local paleogeography and drainage system in the Qilian Shan.

2. The sustained strike-slip motion along the ATF during the entire Mesozoic is responsible for the appearance of synextensional/syntranstensional deposits in basins adjacent to the ATF shearing zone. Regions away from ATF shearing zone evolved in a generally transpressional setting, locally giving way to a contractional setting within fault relay zones or bending.

3. Both the Qilian Shan and the Qaidam Basin have been completely inverted under a N-S or NE-SW oriented compression since the Early Cenozoic.

4. The mechanism driving the extension/transtension in North Tibet during the Jurassic could be related to far-field effects of subduction processes along the southern margins of the continent.

\section{Acknowledgments}

The research was supported by the Key Program of the National Natural Science Foundation of China (grant 41930213) to Guo; State Key Laboratory of Loess and Quaternary Geology, Institute of Earth Environment, CAS, open project fund (SKLLQG1701) to Cheng; and Youth Innovation Promotion Association and West Light Foundation of Chinese Academy of Sciences (XAB2015A01) to Li. Permission of Qinghai Oilfield Company, PetroChina for publication of the subsurface data is acknowledged We would like to thank Editor Uri ten Brink, the anonymous Associate Editor, William Craddock, and another anonymous reviewer for their insightful suggestions that significantly improved the manuscript. We thank Carmala Garzione, Michael Taylor, Andrew Zuza, Michael Murphy, Hanlin Chen, Xiubin Lin, and Lei Wu for the helpful discussion and Carlie Mentzer for improving the English writing. We declare no competing financial interests. The data used are listed in the Supporting information S1 and the Open Science Framework (https://osf. io/kc3ds/?view_only= a5ad8ed50b604d03aa2c425935a74594).

\section{References}

Allen, M. B., Walters, R. J., Song, S., Saville, C., De Paola, N., Ford, J., et al. (2017). Partitioning of oblique convergence coupled to the fault locking behavior of fold-and-thrust belts: Evidence from the Qilian Shan, northeastern Tibetan Plateau. Tectonics, 36, 1679-1698. https://doi.org/10.1002/2017TC004476

Arnaud, N., Tapponnier, P., Roger, F., Brunel, M., Scharer, U., Chen, W., \& Xu, Z. (2003). Evidence for Mesozoic shear along the western Kunlun and Altyn-Tagh fault, northern Tibet (China). Journal of Geophysical Research, 108(B1). 2053. https://doi.org/10.1029/2001JB000904

Bovet, P. M., Ritts, B. D., Gehrels, G., Abbink, A. O., Darby, B., \& Hourigan, J. (2009). Evidence of Miocene crustal shortening in the north Qilian Shan from Cenozoic stratigraphy of the western Hexi Corridor, Gansu Province, China. American Journal of Science, 309(4), 290-329.

Burchfiel, B. C., Quidong, D., Molnar, P., Royden, L., Yipeng, W., Peizhen, Z., \& Weiqi, Z. (1989). Intracrustal detachment within zones of continental deformation. Geology, 17(8), 748-752. https://doi.org/10.1130/0091-7613(1989)017<0448:IDWZOC>2.3.CO;2

Calassou, S. (1994). Etude tectonique d'une chaîne de décollement: Tectonique triasique et tertiaire de la chaîne de Songpan Garzé (est Tibet): Géométrie et cinématique des déformations dans les prismes d'accrétion sédimentaire. Montpellier, 2.

Chen, S., Wang, H., Wei, J., Lv, Z., Gan, H., \& Jin, S. (2014). Sedimentation of the Lower Cretaceous Xiagou formation and its response to regional tectonics in the Qingxi Sag, Jiuquan Basin, NW China. Cretaceous Research, 47, 72-86.

Chen, X., Gehrels, G., Yin, A., Li, L., \& Jiang, R. B. (2012). Paleozoic and Mesozoic Basement Magmatisms of Eastern Qaidam Basin, Northern Qinghai-Tibet Plateau: LA-ICP-MS Zircon U-Pb Geochronology and its Geological Significance. Acta Geologica Sinica English Edition, 86(2), 350-369. https://doi.org/10.1111/j.1755-6724.2012.00665.X

Chen, X., Gehrels, G., Yin, A., Zhou, Q., \& Huang, P. (2015). Geochemical and Nd-Sr-Pb-O isotopic constrains on Permo-Triassic magmatism in eastern Qaidam Basin, northern Qinghai- Tibetan Plateau: Implications for the evolution of the Paleo-Tethys. Journal of Asian Earth Sciences, 114(Part 4), 674-692. https://doi.org/10.1016/j.jseaes.2014.11.013

Chen, X. H., Yin, A., Gehrels, G. E., Cowgill, E. S., Grove, M., Harrison, T. M., \& Wang, X. F. (2003). Two phases of Mesozoic northsouth extension in the eastern Altyn Tagh range, northern Tibetan Plateau. Tectonics, 22(5), 1053. https://doi.org/10.1029/ 2001TC001336

Cheng, F., Fu, S., Jolivet, M., Zhang, C., \& Guo, Z. (2016). Source to sink relation between the Eastern Kunlun Range and the Qaidam Basin, northern Tibetan Plateau, during the Cenozoic. Geological Society of America Bulletin, 128(1-2), 258-283. https://doi.org/10.1130/ b31260.1

Cheng, F., Garzione, C., Jolivet, M., Guo, Z., Zhang, D., \& Zhang, C. (2018). A New Sediment Accumulation Model of Cenozoic Depositional Ages From the Qaidam Basin, Tibetan Plateau. Journal of Geophysical Research: Earth Surface, 123(11), 3101-3121. https:// doi.org/10.1029/2018JF004645

Cheng, F., Garzione, C., Jolivet, M., Guo, Z., Zhang, D., Zhang, C., \& Zhang, Q. (2019). Initial Deformation of the northern Tibetan Plateau: Insights From Deposition of the Lulehe formation in the Qaidam Basin. Tectonics, 38, 741-766. https://doi.org/10.1029/ 2018TC005214

Cheng, F., Garzione, C., Jolivet, M., Wang, W., Dong, J., Richter, F., \& Guo, Z. (2019). Provenance analysis of the Yumen Basin and northern Qilian Shan: Implications for the pre-collisional paleogeography in the NE Tibetan Plateau and eastern termination of Altyn Tagh fault. Gondwana Research, 65, 156-171. https://doi.org/10.1016/j.gr.2018.08.009

Cheng, F., Guo, Z., Jenkins, H. S., Fu, S., \& Cheng, X. (2015). Initial rupture and displacement on the Altyn Tagh fault, northern Tibetan Plateau: Constraints based on residual Mesozoic to Cenozoic strata in the western Qaidam Basin, Geosphere, 11(3), 921-942, doi:https:// doi.org/10.1130/ges01070.1.

Cheng, F., Jolivet, M., Dupont-Nivet, G., Wang, L., Yu, X., \& Guo, Z. (2015). Lateral extrusion along the Altyn Tagh Fault, Qilian Shan (NE Tibet): insight from a 3D crustal budget. Terra Nova, 27(6), 416-425. https://doi.org/10.1111/ter.12173

Cheng, F., Jolivet, M., Fu, S., Zhang, C., Zhang, Q., \& Guo, Z. (2016). Large-scale displacement along the Altyn Tagh Fault (North Tibet) since its Eocene initiation: Insight from detrital zircon U-Pb geochronology and subsurface data. Tectonophysics, 677-678, 261-279. https://doi.org/10.1016/j.tecto.2016.04.023

Cheng, F., Jolivet, M., Hallot, E., Zhang, D., Zhang, C., \& Guo, Z. (2017). Tectono-magmatic rejuvenation of the Qaidam craton, northern Tibet. Gondwana Research, 49, 248-263. https://doi.org/10.1016/j.gr.2017.06.004 
Cheng, F., Cheng, F., Garzione, C. N., Mitra, G., Jolivet, M., Guo, G., Lu, H., et al., (2019). The interplay between climate and tectonics during the upward and outward growth of the Qilian Shan orogenic wedge, northern Tibetan Plateau. Earth-Science Reviews, 198, 102945. https://doi.org/10.1016/j.earscirev.2019.102945

Corfu, F., Hanchar, J. M., Hoskin, P. W., \& Kinny, P. (2003). Atlas of zircon textures. Reviews in mineralogy and geochemistry, 53(1), 469-500. https://doi.org/10.2113/0530469

Coward, M. P., Kidd, W. S. F., Yun, P., Shackleton, R. M., \& Hu, Z. (1988). The structure of the 1985 Tibet geotraverse, Lhasa to Golmud Philosophical Transactions of the Royal Society of London. Series A, Mathematical and Physical Sciences, 327(1594), 307-333. https://doi. org/10.1098/rsta.1988.0131

Cowgill, E., Yin, A., Harrison, T. M., \& Xiao-Feng, W. (2003). Reconstruction of the Altyn Tagh fault based on U-Pb geochronology: Role of back thrusts, mantle sutures, and heterogeneous crustal strength in forming the Tibetan Plateau. Journal of Geophysical Research, 108(B7), 2346. https://doi.org/10.1029/2002JB00208

Darby, B. J., Ritts, B. D., Yue, Y., \& Meng, Q. (2005). Did the Altyn Tagh fault extend beyond the Tibetan Plateau? Earth and Planetary Science Letters, 240(2), 425-435.

Delville, N., Arnaud, N., Montel, J.-M., Roger, F., Brunel, M., Tapponnier, P., \& Sobel, E. (2001). Paleozoic to Cenozoic deformation along the Altyn Tagh fault in the Altun Shan massif area, eastern Qilian Shan, northeastern Tibet, China. Geological Society of America Memoirs, 194, 269-292. https://doi.org/10.1130/0-8137-1194-0.269

Ding, L., Xu, Q., Yue, Y., Wang, H., Cai, F., \& Li, S. (2014). The Andean-type Gangdese Mountains: Paleoelevation record from the Paleocene-Eocene Linzhou Basin. Earth and Planetary Science Letters, 392, 250-264.

ECS (2009). Chinese Stratigraphy. Beijing: Geological Publishing House.

Fang, X., Zhang, W., Meng, Q., Gao, J., Wang, X., King, J., et al. (2007). High-resolution magnetostratigraphy of the Neogene Huaitoutala section in the eastern Qaidam Basin on the NE Tibetan Plateau, Qinghai Province, China and its implication on tectonic uplift of the NE Tibetan Plateau. Earth and Planetary Science Letters, 258(1-2), 293-306.

Fu, L., Guan, P., Zhao, W., Wang, M., Zhang, Y., \& Lu, J. (2013). Uplift of NW margin of Qaidam Basin in the Late Eocene: Implications for the initiation of Altyn Fault. Acta Petrol. Sin., 29(8), 2867-2875.

Fu, S., Ma, D., Guo, Z., and Cheng, F. (2015), Strike-slip superimposed Qaidam Basin and its control on oil and gas accumulation, NW China, Petroleum Exploration and Development, 42(6), 778-789, https://doi.org/10.1016/S1876-3804(15)30074-4

Gehrels, G. E., Yin, A., \& Wang, X. F. (2003). Magmatic history of the northeastern Tibetan Plateau. Journal of Geophysical Research, 108(B9), 2423. https://doi.org/10.1029/2002JB001876

Hanchar, J., \& Rudnick, R. (1995). Revealing hidden structures: the application of cathodoluminescence and back-scattered electron imaging to dating zircons from lower crustal xenoliths. Lithos, 36(3), 289-303. https://doi.org/10.1016/0024-4937(95)00022-4

Harris, N., Ronghua, X., Lewis, C., Hawkesworth, C., \& Yuquan, Z. (1988). Isotope geochemistry of the 1985 Tibet geotraverse, Lhasa to Golmud. Philosophical Transactions of the Royal Society of London. Series A, Mathematical and Physical Sciences, 263-285.

Hendrix, M. S. (2000). Evolution of Mesozoic Sandstone Compositions, Southern Junggar, Northern Tarim, and Western Turpan Basins, Northwest China: A Detrital Record of the Ancestral Tian Shan. Journal of Sedimentary Research, 70(3), 520-532.

Hendrix, M. S., Graham, S. A., Carroll, A. R., Sobel, E. R., McKnight, C. L., Schulein, B. J., \& Wang, Z. (1992). Sedimentary record and climatic implications of recurrent deformation in the Tian Shan: Evidence from Mesozoic strata of the north Tarim, south Junggar, and Turpan basins, northwest China. Geological Society of America Bulletin, 104(1), 53-79.

Hoskin, P. W. O., \& Ireland, T. R. (2000). Rare earth element chemistry of zircon and its use as a provenance indicator. Geology, 28(7), 627-630. https://doi.org/10.1130/0091-7613(2000)28<627:reecoz>2.0.co;2

Hu, X., Wang, J., BouDagher-Fadel, M., Garzanti, E., \& An, W. (2016). New insights into the timing of the India-Asia collision from the Paleogene Quxia and Jialazi formations of the Xigaze forearc basin, South Tibet. Gondwana Research, 32, 76-92.

Hubert, J. F. (1962). A zircon-tourmaline-rutile maturity index and the interdependence of the composition of heavy mineral assemblages with the gross composition and texture of sandstones. Journal of Sedimentary Research, 32(3), 440-450.

Ji, J., Zhang, K., Clift, P. D., Zhuang, G., Song, B., Ke, X., \& Xu, Y. (2017). High-resolution magnetostratigraphic study of the PaleogeneNeogene strata in the Northern Qaidam Basin: Implications for the growth of the northeastern Tibetan Plateau. Gondwana Research, 46 , 141-155.

Jolivet, M. (2015), Mesozoic tectonic and topographic evolution of Central Asia and Tibet: A preliminary synthesis. Geological Society, London, Special Publications, 427, SP427. 422

Jolivet, M., Barrier, L., Dauteuil, O., Laborde, A., Li, Q., Reichenbacher, B., et al. (2018). Late Cretaceous-Palaeogene topography of the Chinese Tian Shan: New insights from geomorphology and sedimentology. Earth and Planetary Science Letters, 499, 95-106. https://doi. org/10.1016/j.epsl.2018.07.004

Jolivet, M., Brunel, M., Seward, D., Xu, Z., Yang, J., Roger, F., et al. (2001). Mesozoic and Cenozoic tectonics of the northern edge of the Tibetan plateau: Fission-track constraints. Tectonophysics, 343(1-2), 111-134. https://doi.org/10.1016/S0040-1951(01)00196-2

Jolivet, M., Roger, F., Arnaud, N., Brunel, M., Tapponnier, P., \& Seward, D. (1999). Histoire de l'exhumation de l'Altun Shan: indications sur l'âge de la subduction du bloc du Tarim sous le système de l'Altyn Tagh (Nord Tibet). Comptes Rendus de l'Académie des SciencesSeries IIA-Earth and Planetary Science, 329(10), 749-755. https://doi.org/10.1016/S1251-8050(00)88495-5

Ke, X., Ji, J., Zhang, K., Kou, X., Song, B., \& Wang, C. (2013). Magnetostratigraphy and Anisotropy of Magnetic Susceptibility of the Lulehe formation in the Northeastern Qaidam Basin. Acta Geologica Sinica-English Edition, 87(2), 576-587. https://doi.org/10.1111/17556724.12069

Kidd, W., Yusheng, P., Chengfa, C., Coward, M. P., Dewey, J. F., Gansser, A., et al. (1988). Geological mapping of the 1985 Chinese-British Tibetan (Xizang-Qinghai) Plateau Geotraverse route. Phil. Trans. R. Soc. Lond. A, 327(1594), 287-305.

Li, H., Yang, J., Xu, Z., Sun, Z., Tapponnier, P., van der Woerd, J., \& Meriaux, A.-S. (2006). The constraint of the Altyn Tagh fault system to the growth and rise of the northern Tibetan Plateau. Earth Science Frontiers, 13(4), 59-79.

Li, L., Guo, Z., Guan, S., Zhou, S., Wang, M., Fang, Y., \& Zhang, C. (2015). Heavy mineral assemblage characteristics and the Cenozoic paleogeographic evolution in southwestern Qaidam Basin. Science China Earth Sciences, 58(6), 859-875. https://doi.org/10.1007/s11430014-5050-x

Li, Z., Song, W., Peng, S., Wang, D., \& Zhang, Z. (2004). Mesozoic-Cenozoic tectonic relationships between the Kuqa subbasin and Tian Shan, northwest China: constraints from depositional records. Sedimentary Geology, 172(3-4), 223-249.

Liu, Y. J., Neubauer, F., Genser, J., Ge, X. H., Takasu, A., Yuan, S. H., et al. (2007). Geochronology of the initiation and displacement of the Altyn Strike-Slip Fault, western China. Journal of Asian Earth Sciences, 29(2), 243-252.

Lou, Q., Lou, Q. Q., Xiao, A. C, Yang, H., Huang, H. S., Ding, Z. Y., Shen, H., et al., (2009). Characteristics of Mesozoic Basin of the Northern Qaidam: A Case Study on Dachaidan Depression. Geological Journal of China Universities, 15(3), 407-416. 
Lu, H., \& Xiong, S. (2009). Magnetostratigraphy of the Dahonggou section, northern Qaidam Basin and its bearing on Cenozoic tectonic evolution of the Qilian Shan and Altyn Tagh Fault. Earth and Planetary Science Letters, 288(3), 539-550.

Meng, Q. R., \& Fang, X. (2008). Cenozoic tectonic development of the Qaidam Basin in the northeastern Tibetan Plateau. Geological Society of America Special Papers, 444, 1-24. https://doi.org/10.1130/2008.2444(01)

Meng, Q. R., Hu, J. M., \& Yang, F. Z. (2001). Timing and magnitude of displacement on the Altyn Tagh fault: constraints from stratigraphic correlation of adjoining Tarim and Qaidam basins, NW China. Terra Nova, 13(2), 86-91.

Meyer, B., Tapponnier, P., Bourjot, L., Metivier, F., Gaudemer, Y., Peltzer, G., et al. (1998). Crustal thickening in Gansu-Qinghai, lithospheric mantle subduction, and oblique, strike-slip controlled growth of the Tibet plateau. Geophysical Journal International, 135(1), 1-47. https://doi.org/10.1046/j.1365-246X.1998.00567.x

Morin, J., Jolivet, M., Robin, C., Heilbronn, G., Barrier, L., Bourquin, S., \& Jia, Y. (2018). Jurassic paleogeography of the Tian Shan: An evolution driven by far-field tectonics and climate. Earth-Science Reviews, 187, 286-313. https://doi.org/10.1016/j. earscirev.2018.10.007

Moseley, B., \& Tsimmer, V. (2000). Evolution and hydrocarbon habitat of the South Turgay Basin, Kazakhstan. Petroleum Geoscience, 6(2), $125-136$.

Pan, B., Li, Q., Hu, X., Geng, H., Liu, Z., Jiang, S., \& Yuan, W. (2013). Cretaceous and Cenozoic cooling history of the eastern Qilian Shan, north-eastern margin of the Tibetan Plateau: evidence from apatite fission-track analysis. Terra Nova, 25(6), 431-438. https://doi.org/ $10.1111 /$ ter.12052

Pei, J., Sun, Z., Wang, X., Zhao, Y., Ge, X., Guo, X., et al. (2009). Evidence for Tibetan plateau uplift in Qaidam basin before EoceneOligocene boundary and its climatic implications. Journal of Earth Science, 20(2), 430-437. https://doi.org/10.1007/s12583-009-0035-y QBGMR (1991). Regional Geology of Qinghai Province, (p. 662). Beijing: Geological Publishing House.

Qi, B., Hu, D., Yang, X., Zhang, Y., Tan, C., Zhang, P., \& Feng, C. (2016). Apatite fission track evidence for the Cretaceous-Cenozoic cooling history of the Qilian Shan (NW China) and for stepwise northeastward growth of the northeastern Tibetan Plateau since early Eocene. Journal of Asian Earth Sciences, 124, 28-41. https://doi.org/10.1016/j.jseaes.2016.04.009

Rieser, A. B., Liu, Y., Genser, J., Neubauer, F., Handler, R., Friedl, G., \& Ge, X. H. (2006a). ${ }^{40} \mathrm{Ar} /{ }^{39} \mathrm{Ar}$ ages of detrital white mica constrain the Cenozoic development of the intracontinental Qaidam Basin, China. GSA Bulletin, 118(11/12), 1522-1534.

Rieser, A. B., Liu, Y., Genser, J., Neubauer, F., Handler, R., \& Ge, X. H. (2006b). Uniform Permian ${ }^{40} \mathrm{Ar} /{ }^{39} \mathrm{Ar}$ detrital mica ages in the eastern Qaidam Basin (NW China): where is the source? Terra Nova, 18(1), 79-87.

Ritts, B. D., \& Biffi, U. (2000). Magnitude of post-Middle Jurassic (Bajocian) displacement on the central Altyn Tagh fault system, northwest China. Geological Society of America Bulletin, 112(1), 61-74. https://doi.org/10.1130/0016-7606(2000)112<61:MOPJBD>2.0.CO;2

Ritts, B. D., \& Biffi, U. (2001). Mesozoic northeast Qaidam basin: Response to contractional reactivation of the Qilian Shan, and implications for the extent of Mesozoic intracontinental deformation in central Asia. Memoirs-Geological Society of America, 293-316.

Ritts, B. D., Hanson, A. D., Zinniker, D., \& Moldowan, J. M. (1999). Lower-Middle Jurassic nonmarine source rocks and petroleum systems of the northern Qaidam basin, northwest China. AAPG bulletin, 83(12), 1980-2005.

Ritts, B. D., Yue, Y., \& Graham, S. A. (2004). Oligocene-Miocene Tectonics and Sedimentation along the Altyn Tagh Fault, northern Tibetan Plateau: Analysis of the Xorkol, Subei, and Aksay Basins. The Journal of geology, 112(2), 207-229. https://doi.org/10.1086/ 381658

Roger, F., Jolivet, M., \& Malavieille, J. (2010). The tectonic evolution of the Songpan-Garzê (North Tibet) and adjacent areas from Proterozoic to Present: A synthesis. Journal of Asian Earth Sciences, 39(4), 254-269.

Sobel, E. R. (1999). Basin analysis of the Jurassic-Lower Cretaceous southwest Tarim basin, northwest China. Geological Society of America Bulletin, 111(5), 709-724.

Sobel, E. R., Arnaud, N., Jolivet, M., Ritts, B. D., \& Brunel, M. (2001). Jurassic to Cenozoic exhumation history of the Altyn Tagh range, northwest China, constrained by 40Ar/39Ar and apatite fission track thermochronology. Geological Society of America Memoirs, 194, 247-267. https://doi.org/10.1130/0-8137-1194-0.247

Sun, Z., Yang, Z., Pei, J., Ge, X., Wang, X., Yang, T., et al. (2005). Magnetostratigraphy of Paleogene sediments from northern Qaidam Basin, China: implications for tectonic uplift and block rotation in northern Tibetan plateau. Earth and Planetary Science Letters, 237(3), 635-646. https://doi.org/10.1016/j.epsl.2005.07.007

Tapponnier, P., Xu, Z. Q., Roger, F., Meyer, B., Arnaud, N., Wittlinger, G., \& Yang, J. S. (2001). Oblique stepwise rise and growth of the Tibet Plateau. Science, 294(5547), 1671-1677. https://doi.org/10.1126/science.105978

Tian, Y., Kohn, B. P., Phillips, D., Hu, S., Gleadow, A. J., \& Carter, A. (2016). Late Cretaceous-earliest Paleogene deformation in the Longmen Shan fold-and-thrust belt, eastern Tibetan Plateau margin: Pre-Cenozoic thickened crust? Tectonics, 35, 2293-2312. https:// doi.org/10.1002/2016TC004182

Vermeesch, P. (2013). Multi-sample comparison of detrital age distributions. Chemical Geology, 341, 140-146.

Vincent, S. J., \& Allen, M. B. (1999). Evolution of the Minle and Chaoshui Basins, China: Implications for Mesozoic strike-slip basin formation in Central Asia. Geological Society of America Bulletin, 111(5), 725-742.

Wang, E., Xu, F.-Y., Zhou, J.-X., Wan, J., \& Burchfiel, B. C. (2006). Eastward migration of the Qaidam basin and its implications for Cenozoic evolution of the Altyn Tagh fault and associated river systems. Geological Society of America Bulletin, 118(3-4), 349-365. https://doi.org/10.1130/b25778.1

Wang, W., Zheng, W., Zhang, P., Li, Q., Kirby, E., Yuan, D., et al. (2017). Expansion of the Tibetan Plateau during the Neogene. Nature communications, 8, 15887.

Wang, X., Qiu, Z., Li, Q., Wang, B., Downs, W. R., Xie, G., et al. (2007). Vertebrate paleontology, biostratigraphy, geochronology, and paleoenvironment of Qaidam Basin in northern Tibetan Plateau. Palaeogeography, Palaeoclimatology, Palaeoecology, 254(3-4), 363-385.

Wang, Y., Zhang, X., Wang, E., Zhang, J., Li, Q., \& Sun, G. (2005). ${ }^{40} \mathrm{Ar} /{ }^{39} \mathrm{Ar}$ thermochronological evidence for formation and Mesozoic evolution of the northern-central segment of the Altyn Tagh fault system in the northern Tibetan Plateau. Geological Society of America Bulletin, 117(9-10), 1336-1346.

Wu, C., Yin, A., Zuza, A. V., Zhang, J., Liu, W., \& Ding, L. (2016). Pre-Cenozoic geologic history of the central and northern Tibetan Plateau and the role of Wilson cycles in constructing the Tethyan orogenic system. Lithosphere, 8(3), 254-292.

Wu, L., Xiao, A., Ma, D., Li, H., Xu, B., Shen, Y., \& Mao, L. (2014). Cenozoic fault systems in southwest Qaidam Basin, northeastern Tibetan Plateau: Geometry, temporal development, and significance for hydrocarbon accumulation. AAPG bulletin, 98(6), 1213-1234.

Wu, L., Xiao, A., Wang, L., Shen, Z., Zhou, S., Chen, Y., et al. (2011). Late Jurassic-Early Cretaceous Northern Qaidam Basin, NW China: Implications for the earliest Cretaceous intracontinental tectonism. Cretaceous Research, 32(4), 552-564. https://doi.org/10.1016/j. cretres.2011.04.002 
Xia, W. C., Zhang, N., Yuan, X. P., Fan, L. S., \& Zhang, B. S. (2001). Cenozoic Qaidam basin, China: A stronger tectonic inversed, extensional rifted basin. AAPG bulletin, 85(4), 715-736.

Yang, F., Ma, Z. Q., Xu, T. C., \& Ye, S. J. (1992). A Tertiary paleomagnetic stratigraphic profile in Qaidam basin (in Chinese with English abstract). Acta Petrolei Sinica, 13(2), 97-101.

Yin, A., Dang, Y. Q., Wang, L. C., Jiang, W. M., Zhou, S. P., Chen, X. H., et al. (2008). Cenozoic tectonic evolution of Qaidam basin and its surrounding regions (Part 1): The southern Qilian Shan-Nan Shan thrust belt and northern Qaidam basin. Geological Society of America Bulletin, 120(7-8), 813-846.

Yin, A., Dang, Y. Q., Zhang, M., Chen, X. H., \& McRivette, M. W. (2008). Cenozoic tectonic evolution of the Qaidam basin and its surrounding regions (Part 3): Structural geology, sedimentation, and regional tectonic reconstruction. Geological Society of America Bulletin, 120(7-8), 847-876. https://doi.org/10.1130/b26232.1

Yin, A., Dang, Y. Q., Zhang, M., McRivette, M. W., Burgess, W. P., \& Chen, X. H. (2007). Cenozoic tectonic evolution of Qaidam basin and its surrounding regions (part 2): Wedge tectonics in southern Qaidam basin and the Eastern Kunlun Range. Geological Society of America Special Papers, 433, 369-390.

Yin, A., \& Harrison, T. M. (2000). Geologic evolution of the Himalayan-Tibetan orogen. Annual Review of Earth and Planetary Sciences, 28 , 211-280. https://doi.org/10.1146/annurev.earth.28.1.211

Yin, A., Rumelhart, P., Butler, R., Cowgill, E., Harrison, T., Foster, D., et al. (2002). Tectonic history of the Altyn Tagh fault system in northern Tibet inferred from Cenozoic sedimentation. Geological Society of America Bulletin, 114, 1257-1295.

Yu, L., Xiao, A., Wu, L., Tian, Y., Rittner, M., Lou, Q., \& Pan, X. (2017). Provenance evolution of the Jurassic northern Qaidam Basin (West China) and its geological implications: evidence from detrital zircon geochronology. International Journal of Earth Sciences, 106(8), 2713-2726. https://doi.org/10.1007/s00531-017-1455-z

Yue, Y., \& Liou, J. (1999). Two-stage evolution model for the Altyn Tagh fault, China. Geology, 27(3), 227-230.

Yue, Y. J., Ritts, B. D., \& Graham, S. A. (2001). Initiation and long-term slip history of the Altyn Tagh Fault. International Geology Review, 43(12), 1087-1093. https://doi.org/10.1080/00206810109465062

Zhang, H., Lu, H., Xu, X., Liu, X., Yang, T., Stevens, T., et al. (2016). Quantitative estimation of the contribution of dust sources to Chinese loess using detrital zircon U-Pb age patterns. Journal of Geophysical Research: Earth Surface, 121, 2085-2099.

Zhang, M. (2012), A study on the distribution regularity of Mesozoic strata within oil source lithologic hydrocarbon reservoir of Suganhu depression in North Qaidam, Master thesis, 65 pp, Jilin University, Jilin.

Zhang, W. (2006). High-resolution megnetostratigraphy of the Cenozoic Qaidam Basin, implications for the uplift of Tibetan Plateau (in Chinese with English abstract). Lanzhou: LanZhou University.

Zhuang, G., Hourigan, J. K., Ritts, B. D., \& Kent-Corson, M. L. (2011). Cenozoic multiple-phase tectonic evolution of the northern Tibetan Plateau: Constraints from sedimentary records from Qaidam basin, Hexi Corridor, and Subei basin, northwest China. American Journal of Science, 311(2), 116-152. https://doi.org/10.2475/02.2011.02

Zuza, A. V., Wu, C., Reith, R. C., Yin, A., Li, J., Zhang, J., et al. (2017). Tectonic evolution of the Qilian Shan: An early Paleozoic orogen reactivated in the Cenozoic. GSA Bulletin, 130(5-6), 881-925. https://doi.org/10.1130/B31721.1 